Article

\title{
A Comparative Analysis of Soil Loss Tolerance and Productivity of the Olive Groves in the Protected Designation of Origin (PDO) Areas Norte Alentejano (Portugal) and Estepa (Andalusia, Spain)
}

\author{
Antonio Alberto Rodríguez Sousa ${ }^{1, * \mathbb{C}}$, José Muñoz-Rojas ${ }^{2}\left(\mathbb{D}\right.$, Teresa Pinto-Correia ${ }^{2} \mathbb{C}$, Pedro A. Aguilera ${ }^{3, * \mathbb{C}}$, \\ Jesús M. Barandica ${ }^{1}$ (I) and Alejandro J. Rescia ${ }^{1, *(\mathbb{D}}$ \\ 1 Teaching Unit of Ecology (UDECO), Department of Biodiversity, Ecology and Evolution (BEE), \\ Faculty of Biological Sciences, University Complutense of Madrid, 28040 Madrid, Spain; jmbarand@ucm.es \\ 2 MED-Mediterranean Institute for Agriculture, Environment and Development, Universidade de Évora, \\ Núcleo da Mitra Gab. 206, Edificio dos Regentes Agrícolas, Apartado 94, 7006-554 Évora, Portugal; \\ jmrojas@uevora.pt (J.M.-R.); mtpc@uevora.pt (T.P.-C.) \\ 3 Department of Biology and Geology, University of Almería, 04120 Almería, Spain \\ * Correspondence: antonr05@ucm.es (A.A.R.S.); aguilera@ual.es (P.A.A.); alejo296@bio.ucm.es (A.J.R.); \\ Tel.: +34-91-394-50-85 (A.A.R.S.)
}

check for updates

Citation: Rodríguez Sousa, A.A.; Muñoz-Rojas, J.; Pinto-Correia, T.; Aguilera, P.A.; Barandica, J.M.; Rescia, A.J. A Comparative Analysis of Soil Loss Tolerance and Productivity of the Olive Groves in the Protected Designation of Origin (PDO) Areas Norte Alentejano (Portugal) and Estepa (Andalusia, Spain). Agronomy 2021, 11, 665. https://doi.org/ 10.3390/agronomy11040665

Academic Editor:

Jacynthe Dessureault-Rompré

Received: 28 February 2021

Accepted: 27 March 2021

Published: 31 March 2021

Publisher's Note: MDPI stays neutral with regard to jurisdictional claims in published maps and institutional affiliations.

Copyright: (c) 2021 by the authors. Licensee MDPI, Basel, Switzerland. This article is an open access article distributed under the terms and conditions of the Creative Commons Attribution (CC BY) license (https:/ / creativecommons.org/licenses/by/ $4.0 /)$.
Abstract: Olive groves are Mediterranean systems that occupy more than $2.5 \mathrm{M}$ ha in Spain and $0.352 \mathrm{M}$ ha in Portugal. Assuming the differences between both countries in terms of olive grove regulation and considering their multifunctionality, it is useful to implement agronomic indices to estimate their sustainability. The Soil Loss Tolerance Index (SLTI) and the Soil Productivity Index (SPI) are two such indices. We calculated both indices in the Protected Designation of Origin (PDO) Norte Alentejano (Portugal). The SLTI index was adapted considering specific variables of the analysed olive groves (i.e., SLTIog). The values obtained were compared with those previously estimated for PDO Estepa (Spain). The negative impacts of erosion and the underlying agricultural practices on the sustainability of olive groves became evident, resulting in decreased soil productivity at the regional level. The SLTIog index showed higher values for crops, being a more realistic tool to analyse sustainability. A higher soil loss tolerance was detected for integrated groves in the PDO Norte Alentejano than for PDO Estepa due to the shorter age of olive cultivation in Portugal, with incipient soil impacts. These indices provide information on the degree of soil erosion, allowing farmers and decision-makers to apply practices to maximise the sustainability of olive groves.

Keywords: conservation agriculture; edaphology; soil erosion; farm management practices; olive groves; sustainability; soil productivity

\section{Introduction}

Across the European Union (EU), agricultural crops currently occupy 175 million hectares ( $\mathrm{M} \mathrm{ha}$ ), of which $5 \mathrm{M}$ ha correspond to olive groves [1]. Olive groves, as socioecological and cultural landscapes, are widely represented in southern Europe, especially in the Iberian Peninsula where they occupy $2.82 \mathrm{M}$ ha [2]. Of these, more than $2.5 \mathrm{M}$ ha are in Spain, resulting from long-term landscape histories with multiple cultural values. In Portugal there are currently 352,000 ha, considered an incipient crop in terms of agricultural expansion and intensification [3,4]. These agricultural socio-ecological landscapes are inherently multifunctional, with a primary economic function, contributing $6 \%$ and $1.36 \%$ to the national farm income in Spain and Portugal. In addition, they also perform an important societal function by generating $10 \%$ and $1.60 \%$ of rural employment in Spain and Portugal, respectively. Lastly, olive groves play a key societal role by delivering multiple ecosystem services (ES), and they also shape key environmental a cultural values of 
Mediterranean landscape character [5-7]. The main contribution of olive groves to society is the supply ES (i.e., olive oil and table olive). While Spain is the world's leading oil producer, with an annual average of $1.53 \mathrm{M} \mathrm{t}$ year $^{-1}$, Portugal produces $76,200 \mathrm{t} \mathrm{year}^{-1}[2,8]$. Other olive groves' contributions to society relate to regulating ES, such as $\mathrm{CO}_{2}$ sequestration, mitigation of climate change and soil erosion processes, and pest control; cultural ES, such as maintenance of cultural landscape character and associated employment and olive oil tourism; and supporting ES, acting as agro-biodiversity reservoirs that host up to $25 \%$ of the species of birds, $20 \%$ of the insects, and $17 \%$ of the flora of the Iberian Peninsula [9-11].

Olive groves in Andalusia, where they occupy an area of $1.5 \mathrm{M}$ ha, are largely found as part of the rural landscape matrix of agricultural monocultures. In Portugal, on the other hand, it is still an expanding crop, with the highest concentration in Alentejo, with almost 200,000 ha, where $28.1 \%$ of the olive groves are intensively managed [12,13]. The Spanish legislation regulating olive grove management practices is extensive, including the Master Plan for the Andalusian Olive Groves and the Olive Grove Law [6,14]. In contrast in Portugal, actions for the multifunctionality and sustainability of olive groves are much more recent, and the regulatory framework remains fragmented, with policy tools focusing on individual aspects of the system, such as preventing the cutting of olive trees or regulating the price of water, in keeping with the generic European regulations $[15,16]$. Thus, more effective policies and regulations are needed in Portugal at the regional/local level in order to encourage the valorisation of these crops and promote the implementation of management practices aimed at maximising their durability $[7,10]$.

Most Spanish olive systems are managed under a rainfed regime, but in recent years irrigated olive groves have been expanding and now account for $32.2 \%$ of the total, using mostly a deficit/drip type of irrigation, where water is incorporated into the crop in times of water stress $[17,18]$. In Portugal, on the other hand, the area of irrigated olive groves is $23 \%$, with the presence of Alqueva reservoir, which is located in Alentejo region, with an area of $250 \mathrm{~km}^{2}$ and a maximum storage capacity of $4150 \mathrm{hm}^{3}$ of water [19]. In this sense, considering water addition as a measure of agricultural intensification, it is necessary to carry out studies that analyse the influence of irrigation on the edaphic environment, quantifying its physical-chemical degradation and related consequences on the economic-ecological sustainability of olive grove landscapes and ecosystems $[5,12,13$, 17]. Overall, olive grove management has traditionally been extensive, using chemical fertilisers and machinery only in the face of slopes lower than $20 \%[18,20]$. However, in recent decades, driven by market instabilities and globalisation, farmers have been forced to opt for different management options. One of these options is the abandonment of smallholder and less profitable farms [21]; another is the intensification of crops, increasing the productivity of the farming systems based on the uncontrolled use of chemicals as energy inputs [22]; or, finally, the adoption of multifunctional management models that balance the socio-economic, cultural, productive, and environmental dimensions of the crops. Within multifunctional agriculture, integrated and organic management models stand out. These are options which promote the implementation of agri-environmental practices to maximise sustainability standards through the controlled use of irrigation and chemical or organic fertilisers, respectively [23,24].

Despite the relevance of olive farming systems as socio-ecological landscapes and providers of ES, there are multiple economic (i.e., low farm income), social (i.e., rural abandonment), and environmental (i.e., soil and ecosystem degradation) threats that endanger their sustainability $[10,21,22]$. Among the environmental threats, the impacts of entomological pests over agronomic productivity and the consequences of climate change in the medium to long term on the distribution area of olive groves stand out. Nonetheless soil erosion processes might be considered overall as the main threat to the agricultural sustainability of olive groves $[6,7,9,13]$. In this sense, soil loss and the dragging of materials on the surface (i.e., runoff) causes edaphic degradation that hampers the economic profitability and environmental conservation of these systems, threatening the continuity of agricultural activities [5,12]. Thus, it is extremely important to carry out studies that analyse how to 
mitigate the consequences of erosion in agriculture, maintaining the productive, socioeconomic and environmental dimensions of olive groves in a balanced way [18,24]. A very useful approach to analyse the consequences of erosion on agricultural sustainability is the implementation of generic agronomic indices such as the Soil Loss Tolerance Index (SLTI) and its specific modifications for certain crops, such as olive groves (i.e., SLTIog). These indices stablish the maximum threshold of soil loss tolerated to guarantee the durability and multifunctionality of a crop in the face of different timescale projections, enabling technical staff and decision-makers to implement agricultural conservation measures to increase farming sustainability $[25,26]$. The Soil Productivity Index (SPI) is equally relevant, quantifying the edaphic productive potential of any agricultural system, providing information on its profitability $[27,28]$.

The scarce existing agricultural regulation in Portugal at the legislative level combined with the intrinsic vulnerability and instability of olive groves, whose development and exploitation is in its early stages in Portugal, demands, as the general objective of this research, the implementation of tools for estimating their productive and environmental sustainability with the aim of guaranteeing a stable food supply to society while maintaining their multifunctionality $[10,11,17,24]$. Considering the socio-cultural and economic relevance of olive groves in the Iberian Peninsula, and the differences in their management models and legislation between Spain and Portugal, a comparative study was carried out which compares a Portuguese olive grove with European certification and previous studies carried out in an olive grove of a Protected Designation of Origin (PDO) in Southern Spain. In Portugal, the study area was the PDO Norte Alentejano, with a surface of approximately 1350 ha of olive groves largely managed in either traditional, integrated, or intensive ways, and an annual total production of 170 tons $(t)$ of olive oil [13,29]. In Spain, a comparison was made with PDO Estepa (Seville, Andalusia, Spain), which hosts almost 40,000 ha of olive groves and a production of 30,000 t of oil per year [30]. The specific objectives of this study were (a) estimating the SLTI and SPI indices in the PDO Norte Alentejano as a proxy of agronomic sustainability; (b) calibrating and implementing specific modifications of the SLTI for the olive grove management models present in the study area, considering the influence of edaphic variables as potential mitigating agents of erosive processes (i.e., SLTIog); and (c) comparatively evaluating the results obtained with similar studies carried out in the PDO Estepa [31].

\section{Materials and Methods}

\subsection{Study Area}

The main study area of this research corresponded to the PDO Norte Alentejano (Portugal). However, a comparison with previous results postulated for the PDO Estepa (Seville, Andalusia, Spain) was also carried out (Figure 1).

PDO Norte Alentejano was registered in 2005 at the European level. The area has a hotsummer Mediterranean climate, with an average temperature of $16.3^{\circ} \mathrm{C}$ and an average annual rainfall of $582 \mathrm{~mm}$, with gentle slopes and an altitude between 200 and $600 \mathrm{~m}$ above sea level (m.a.s.l.). Olive groves are spatially scattered within a landscape mosaic dominated by cork oak and holm oak wood pastures [13,29,32-34]. The soils in which olive trees are grown have a depth of up to $150 \mathrm{~cm}$, with loam or sandy-loam textures, being mainly calcareous and highly susceptible to erosion [35,36]. Specifically, olive farming systems are largely located on land with a slope of less than $15 \%$ where laminar/sheet erosion predominates $[1,27]$. The characteristic soils in this region have a high content of limestone, intrusive igneous rocks (i.e., granite) with quartz, feldspar, plagioclase and mica, and laminar metamorphic and sedimentary schists [14,32]. In Alentejo, water availability is being rapidly transformed due to the presence of the Alqueva reservoir, with public irrigation permissions. Access to these permissions allows deficit/drip irrigation to be applied in certain farms (i.e., the incorporation of up to $1500 \mathrm{~m}^{3}$ of water ha ${ }^{-1}$ during water stress), except for intensive management, where water addition responds directly to crop demand with no regulated maximum limit $[19,37]$. In consequence, olive grove 
management models implemented in the PDO Norte Alentejano include the following: (a) Traditional mechanised groves in soils with a slope of $<20 \%$ covering $46 \%$ of the olive grove area in this region. The plant density of these crops is $<140$ trees $^{-1}$, and the use of chemical fertilisers is allowed [38,39]. (b) Integrated management, with crops representing $45 \%$ of the PDO, with a planting density between 140 and 399 trees ha $^{-1}$, where the addition of synthetic fertilisers is regulated by technical control agencies [30,39]. (c) Intensive management ( $9 \%$ of the olive grove land within the PDO), with a plant density higher to 400 trees $\mathrm{ha}^{-1}$, and with use of agricultural machinery, irrigation, and fertilisers indiscriminately permitted [20,37].

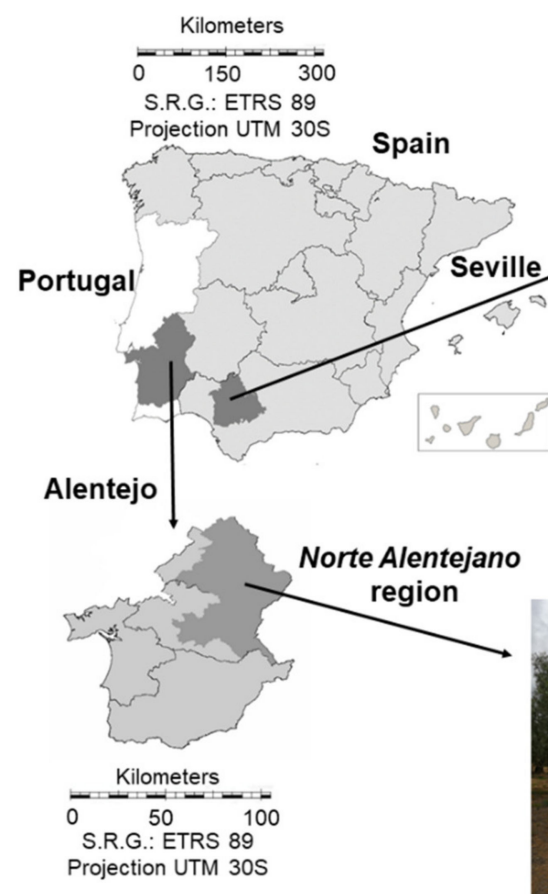

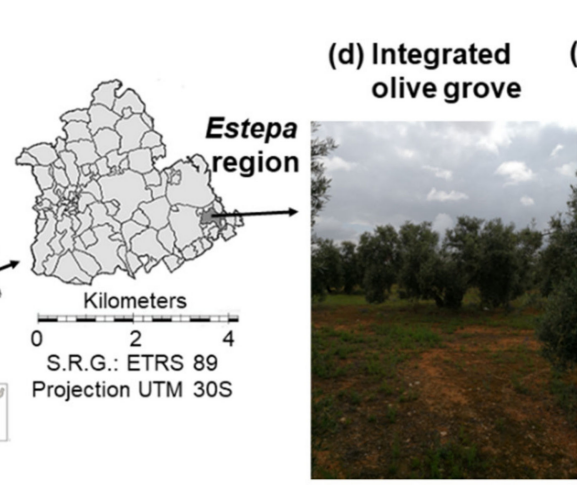

(a) Traditional olive grove

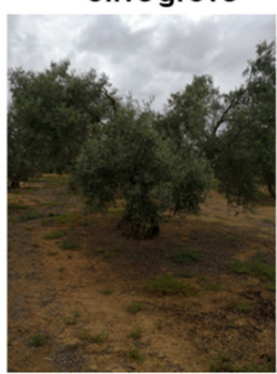

(b) Integrated olive grove

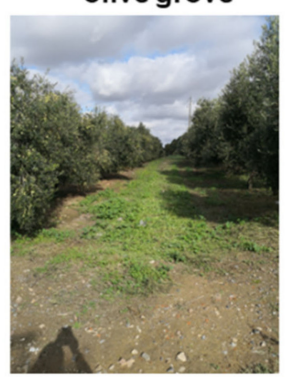

(e) Organic
olive grove

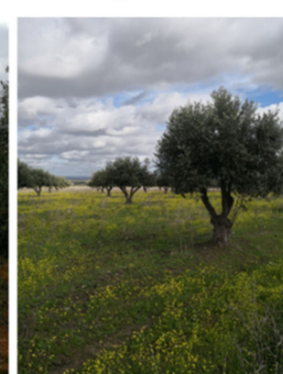

(c) Intensive olive grove

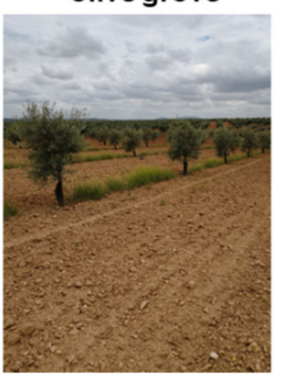

Figure 1. Geographical location of the Protected Designation of Origin (PDO) Norte Alentejano, including the olive management models: (a) traditional olive grove; (b) integrated olive grove; and (c) intensive olive grove. The PDO Estepa is also shown, where olive groves may be under integrated (d) or organic (e) management.

The PDO Estepa was registered with the European Union in 2010, covering a total area of 39,694 ha of olive groves scattered across another 20,000 ha of relict vegetation [6,24]. This region has an altitude between 200 and 800 m.a.s.1., and a continental Mediterranean climate characterised by an average temperature of $17.5^{\circ} \mathrm{C}$ and $477 \mathrm{~mm}$ of annual rainfall [30]. Olive trees are hereby gown on loam and calcareous soils of great depth (i.e., 30-150 cm), with a planting density of 100-500 trees ha ${ }^{-1}$ [24,31]. From a geological point of view, calcareous soils (i.e., Albariza type) predominate, with a low water absorption capacity together with a medium-high mechanical resistance, being highly susceptible to laminar erosion (i.e., losses of over $35 \mathrm{t} \mathrm{ha}^{-1}$ year $^{-1}$ of soil) $[6,29]$. This fact results in a uniform soil loss where materials are dragged from the edaphic surface, generating gullies in the territory, threatening the sustainability of the olive grove $[20,28]$. Although the majority of these systems are rainfed, $10 \%$ of the olive area depends on deficit/drip irrigation, with farms vastly managed under integrated models. Additionally, this region presents an incipient development of organic rainfed olive groves, where only the use of organic fertilisers is allowed (i.e., $500 \mathrm{ha}$ ) [6,20,40]. 


\subsection{Sample Design, Data Collection, and Treatments}

\subsubsection{Protected Designation of Origin (PDO) Norte Alentejano (Portugal)}

PDO Norte Alentejano currently includes three types of olive grove management models, depending on the density of planting and the energy inputs applied to the crop: (a) traditional management, (b) integrated management, and (c) intensive management. The olive groves belonging to this region are located in areas with slopes of up to $15 \%$ and are considered to be plain olive groves where the use of agricultural machinery is allowed [19]. Although the majority of olive groves are managed under rainfed systems (i.e., $77 \%$ of olive groves), it should be noted that the high water availability in the study area means that all farms can generally implement the addition of deficit/drip irrigation during times of summer drought [41,42].

For the sampling and selection of the farming plots, the study area was stratified according to the three olive grove management models identified and also according to the soil erosion ranks that can be classified based on both the slope and the pattern of land use and land covers, using cadastral and land use information from different geo-spatial data and sources and repositories such as CORINE Land Cover and Epic WebSIG Portugal (i.e., including the use of Digital Elevation Models, DEM) $[43,44]$. Based on such information and assuming the general character for estimating soil losses from the Universal Soil Loss Equation (USLE) [45,46], the study area was classified into different erosive states following the classification postulated by Moreira-Madueño for agricultural crops according to the slope of the territory [47]. Bearing in mind that in the PDO Norte Alentejano, laminar erosion phenomena predominate, which can lead to edaphic gullies due to the entrainment of soil particles at the surface. The USLE was estimated specifically for the study area as follows:

$$
\mathrm{A}=\mathrm{R} \times \mathrm{K} \times \mathrm{LS} \times \mathrm{C} \times \mathrm{P},
$$

where A: annual soil losses ( $\mathrm{t} \mathrm{ha}^{-1}$ year $\left.^{-1}\right)$; R: rain erosivity $\left(\mathrm{J} \mathrm{ha}^{-1}\right)$; $\mathrm{K}$ : soil erodibility $\left(\mathrm{Mg} \mathrm{J}^{-1}\right)$; LS: length and degree of slopes (dimensionless, also in \%); C: ground cover (dimensionless); P: agricultural conservation practices (dimensionless).

Key references in the recent literature addressing the overall Alentejo region and for the case study area were used to calibrate the R and LS factors of the USLE model (Equation (1)) [47,48]. Factor K was alternatively estimated, following the experimental criteria set by Gisbert Blanquer et al. [49] and Auerswald et al. [50]. Factor C was calibrated following the criteria by Gómez et al. [51]. This last factor varies with the type of land management practices implemented based on (a) olive tree density (considered minimum in traditional olive groves, medium in integrated and organic management types, and higher in intensive agriculture); (b) canopy diameter (maximum in traditional, integrated, and organic management olive grove types and minimum in intensive olive groves); and (c) extent (width) of ground cover (partial in traditional and integrated olive groves, maximum in organic olive groves, and null in intensive ones).

Following these criteria, factor $C$ was assigned a value of 0.25 for traditional olive groves in response to the presence of partial vegetation cover and adult olive groves (i.e., $>50$ years) of approximately a $2.5 \mathrm{~m}$ radius and also of inter-rows at least $2 \mathrm{~m}$ wide. In the case of integrated olive groves in the study area, considering that the structural characteristics of the traditional olive groves are maintained unchanged, but the inter-rows are widened to $4 \mathrm{~m}$ and the olive trees are between 5-49 years old, factor $C$ was assigned a value of 0.16 . Lastly, in intensive olive groves this factor was assigned a value of 0.41 , due to the absence of plant covers, to the presence young trees (i.e., $<5$ years) of a $1 \mathrm{~m}$ radius, and inter-rows of $2 \mathrm{~m}$. Finally, factor $\mathrm{P}$ was assigned an equal value of 1 for all management models, assuming similar characteristics to those considered for the PDO Estepa (i.e., farms are subject to tillage practices without any control of erosion) [31,40]. Table 1 shows the parameters of the USLE model as calibrated for the PDO Norte Alentejano. 
Table 1. Estimation of soil loss rates (A, in $\mathrm{tha}^{-1} \mathrm{year}^{-1}$ ), according the Universal Soil Loss Equation (USLE), where R: rain erosivity $\left(\mathrm{J} \mathrm{ha}^{-1}\right)$; $\mathrm{K}$ : soil erodibility $\left(\mathrm{Mg} \mathrm{J}^{-1}\right)$; LS: length and degree of slopes (dimensionless and in \%); C: ground cover (dimensionless); and P: agricultural conservation practices (dimensionless). USLE has been calibrated for traditional, integrated, and intensive olive groves, considering all soil erosion levels, in the PDO Norte Alentejano.

\begin{tabular}{cccccccc}
\hline \multirow{2}{*}{ Management } & Erosion Level & \multicolumn{9}{c}{ Factors } & \multirow{2}{*}{ A } \\
\cline { 3 - 6 } & & $\mathbf{R}$ & $\mathbf{K}$ & $\mathbf{L S}$ & $\mathbf{C}$ & $\mathbf{P}$ & \\
\hline \multirow{4}{*}{ Traditional } & Null & 95 & 0.52 & $0.00(0 \%)$ & 0.25 & 1 & 0.00 \\
& Slight & 95 & 0.52 & $0.18(3 \%)$ & 0.25 & 1 & 2.24 \\
& Moderate & 95 & 0.68 & $0.70(7 \%)$ & 0.25 & 1 & 11.37 \\
& Severe & 95 & 0.52 & $2.20(15 \%)$ & 0.25 & 1 & 27.03 \\
\hline \multirow{4}{*}{ Integrated } & Null & 95 & 0.60 & $0.00(0 \%)$ & 0.16 & 1 & 0.00 \\
& Slight & 95 & 0.54 & $0.18(3 \%)$ & 0.16 & 1 & 1.47 \\
& Moderate & 95 & 0.73 & $0.70(7 \%)$ & 0.16 & 1 & 7.81 \\
& Severe & 95 & 0.61 & $2.20(15 \%)$ & 0.16 & 1 & 20.29 \\
\hline \multirow{5}{*}{ Intensive } & Null & 95 & 0.44 & $0.00(0 \%)$ & 0.41 & 1 & 0.00 \\
& Slight & 95 & 0.56 & $0.18(3 \%)$ & 0.41 & 1 & 3.93 \\
& Moderate & 95 & 0.45 & $0.70(7 \%)$ & 0.41 & 1 & 12.38 \\
& Severe & 95 & 0.35 & $2.20(15 \%)$ & 0.41 & 1 & 30.05 \\
\hline
\end{tabular}

The erosion categories/levels vary depending essentially on soil erodibility and ground cover (K and C) factors. Based on cadastral information [43,44], all olive farms presented representative crop plots for each possible erosion level considered. Thus, according to the combination of the various classes defined in this PDO for olive grove management models and soil erosion levels, 12 treatments were identified. Within each treatment, four plots were randomly sampled, resulting in a final sample size of $n=48$ plots (Figure 2).

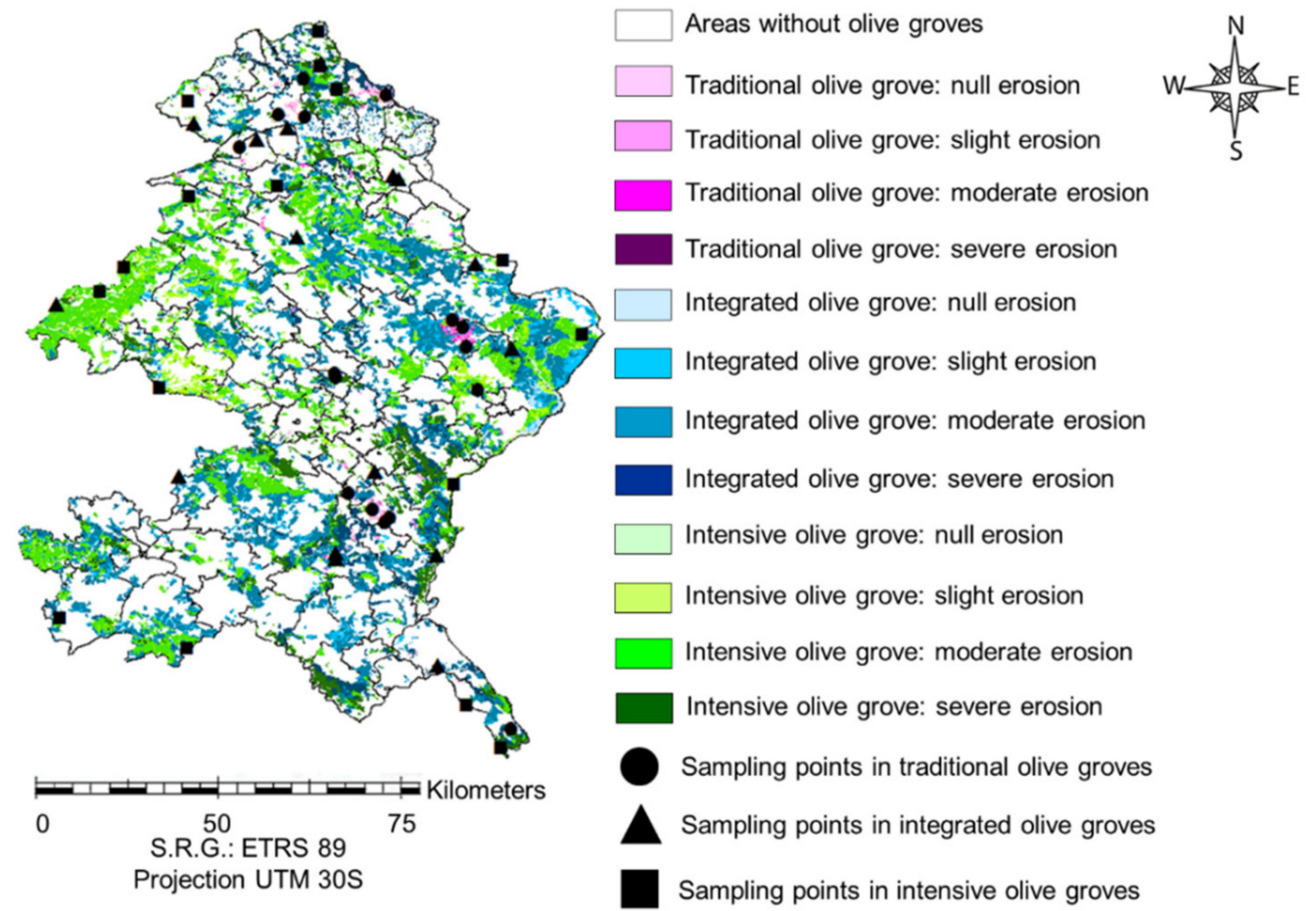

Figure 2. Sampling design carried out in the PDO Norte Alentejano, incorporating olive grove management, soil erosion levels, and sampling points.

In each sampling plot, a $1 \mathrm{~km}$ long and $5 \mathrm{~m}$ wide transect was delimited, on each of which three soil samples with a core of $112.40 \mathrm{~g}$ (weight) and $141.37 \mathrm{~cm}^{3}$ (volume) were collected. Additionally, soil depth was obtained from the DEM used [43,44]. Samples were 
dried at $105{ }^{\circ} \mathrm{C}$ over $24 \mathrm{~h}$. For the calculation of the three agricultural indices proposed, the main physical-chemical soil variables analysed shown in Table 2 were measured.

Table 2. Edaphic variables analysed indicating their abbreviation and unit, utility, and the procedure followed to calculate each of them, including references (Equation and Methodology), whereby W: weight (gr); V: volume $\left(\mathrm{cm}^{3}\right)$.

\begin{tabular}{|c|c|c|}
\hline Variable (Unit) & Utility & Equation and Methodology \\
\hline $\begin{array}{c}\left.\text { Dry bulk density (DBD, gr cm }{ }^{-3}\right) \\
\text { Soil depth }(\mathrm{D}, \mathrm{cm})\end{array}$ & $\begin{array}{l}\text { Soil compaction indicator } \\
\text { Soil depth }\end{array}$ & 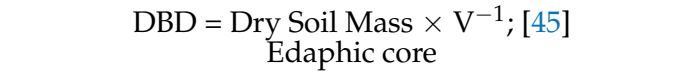 \\
\hline $\begin{array}{l}\text { Soil weight } \\
\left(\mathrm{W}, \mathrm{t} \mathrm{ha}^{-1}\right)\end{array}$ & Quantity of soil per unit area & $\mathrm{W}=100 \times \mathrm{D} \times \mathrm{DBD} ;[45]$ \\
\hline $\begin{array}{c}\text { Equivalence } 1 \mathrm{t} \text { soil }(\mathrm{Eq}, \mathrm{mm}) \\
\text { Gravel }(\mathrm{G}, \%)\end{array}$ & $\begin{array}{l}\text { Conversion factor } \mathrm{t} \text { to } \mathrm{mm} \\
\text { Soil structural indicator }\end{array}$ & $\begin{array}{c}\mathrm{Eq}=1 \times(\mathrm{DBD} \times 10)^{-1} ;[27,28] \\
\text { Sample sieving; }[52,53]\end{array}$ \\
\hline $\begin{array}{l}\text { Sands }(\mathrm{S}, \%) \\
\text { Silts }(\mathrm{Sl}, \%) \\
\text { Clays }(\mathrm{Cl}, \%)\end{array}$ & $\begin{array}{l}\text { Soil textural indicators. USDA criteria } \\
\text { (sands: } 2 \mathrm{~mm}-50 \mu \mathrm{m} ; \text { silts: } 50 \mu \mathrm{m}-2 \mu \mathrm{m} \text {; } \\
\text { clays: }<2 \mu \mathrm{m})\end{array}$ & Bouyoucos Densitometer; [53,54] \\
\hline Texture $(\mathrm{T},-)$ & Soil textural classification & Textures triangle; [55] \\
\hline Porosity $(\mathrm{P}, \%)$ & Total amount of soil pores & $\begin{array}{c}\text { V sample }-\mathrm{V} \text { dry soil }=\mathrm{V} \text { pores; } \\
\% \mathrm{P}=\left(\mathrm{V} \text { pores } \times \mathrm{V} \text { core }^{-1}\right) \times 100 ;[52]\end{array}$ \\
\hline Moisture (M, \%) & Amount of soil pores with water & $\begin{array}{l}\text { W sample }+ \text { water }-\mathrm{W} \text { dry soil }=\mathrm{W} \text { water; } \\
\% \mathrm{M}=\left(\mathrm{W} \text { water } \times \mathrm{W} \text { sample }+ \text { water }^{-1}\right) \times 100 ; \text { [52] }\end{array}$ \\
\hline $\begin{array}{c}\mathrm{pH}(-) \\
\text { Organic matter }(\mathrm{OM}, \%)\end{array}$ & $\begin{array}{l}\text { Indicator of acidity or alkalinity of soil } \\
\text { Soil fertility indicator }\end{array}$ & $\begin{array}{c}\text { Direct estimation } \\
\mathrm{OM}=1.724 \times[\text { carbon }] ;[56]\end{array}$ \\
\hline Potassium $\left(\mathrm{K}, \mathrm{mg} \mathrm{kg}^{-1}\right)$ & Diffuse contamination indicator & Flame photometry; [57] \\
\hline
\end{tabular}

2.2.2. Measuring Soil Erosion in Olive Groves of the PDO Estepa (Seville, Andalusia, Spain): Brief Methodological Foundations

This task was based on previous research published by Sousa et al. [31], where a similar methodology to the one hereby defined for the PDO Norte Alentejano (Portugal) had been implemented. In the PDO Estepa there are currently two olive grove management models: (a) integrated with rainfed or with an irrigation regime and (b) rainfed organic on isolated plots. Following the USLE (Equation (1)) to estimate laminar erosion in this area, due to the plain relief of the olive groves (i.e., slopes up to $15 \%$ ), these crops were classified accordingly based on the same two criteria of soil erosion and land management practices (Figure 3), resulting in eight treatments taking into account the representativeness of the integrated rainfed plots in all erosion levels (i.e., null with a $0 \%$ slope, slight with a $3 \%$ slope, moderate with a $7 \%$ slope, and severe with a $15 \%$ slope), the existence of integrated irrigated groves only in moderate and severe erosion levels, and the representativeness of organic plots only in lands with null and moderate erosion: (a) integrated rainfed olive grove with null (soil loss $(\mathrm{A})=0.00 \mathrm{tha}^{-1}$ year $\left.^{-1}\right)$, (b) slight $\left(\mathrm{A}=2.81 \mathrm{t} \mathrm{ha}^{-1}\right.$ year $\left.^{-1}\right)$, (c) moderate $\left(\mathrm{A}=6.88 \mathrm{tha}^{-1}\right.$ year $\left.^{-1}\right)$, and $(\mathrm{d})$ with severe soil erosion $\left(\mathrm{A}=36.68 \mathrm{tha}^{-1}\right.$ year $\left.{ }^{-1}\right)$; (e) irrigated integrated olive grove with moderate $\left(\mathrm{A}=6.88 \mathrm{tha}^{-1}\right.$ year $\left.^{-1}\right)$, and (f) with severe soil erosion $\left(\mathrm{A}=36.68 \mathrm{t} \mathrm{ha}^{-1}\right.$ year $\left.^{-1}\right)$; and $(\mathrm{g})$ rainfed organic olive grove with null $\left(\mathrm{A}=0.00 \mathrm{t} \mathrm{ha}^{-1} \mathrm{year}^{-1}\right)$, and $(\mathrm{h})$ with moderate soil erosion $\left(\mathrm{A}=2.58 \mathrm{t} \mathrm{ha}^{-1}\right.$ year $\left.^{-1}\right)$.

Based on this categorisation of olive groves, four plots in each category were sampled, with a final sample size of $n=32$ plots. In each of these plots, soil samples were collected from which the soil physical-chemical parameters required to compute the Soil Loss Tolerance Indices applied to agriculture and olive groves (i.e., SLTI and SLTIog) and the Soil Productivity Index (i.e., SPI) were then calculated. 


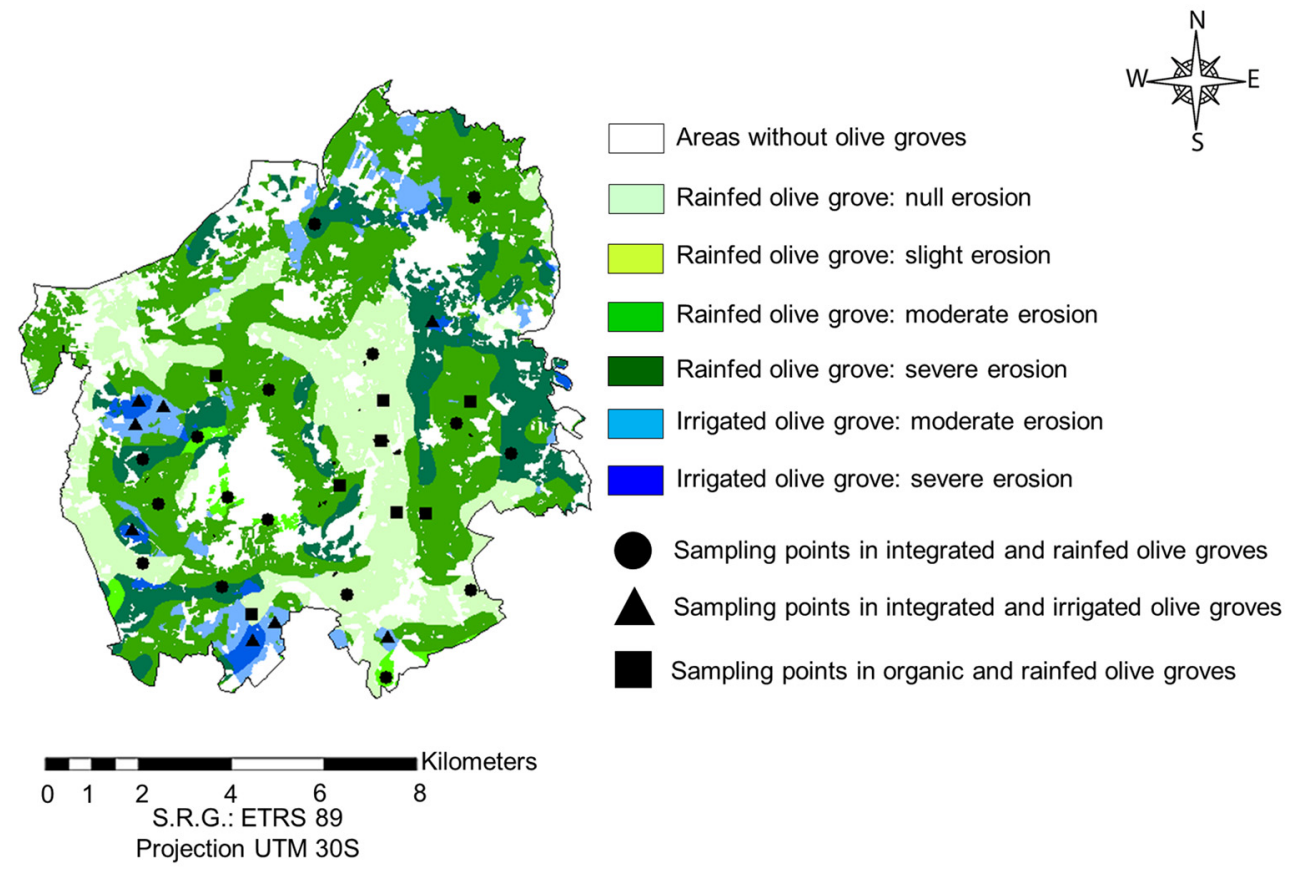

Figure 3. Sampling design carried out in previous studies in the PDO Estepa. The water regimes of the study area are shown (i.e., rainfed and irrigated), together with the erosive states (i.e., null, slight, moderate, and severe). The olive grove of the whole study area is managed in an integrated way, with the exception of isolated plots managed in an organic way.

\subsection{Calculation of Agricultural Indices}

\subsubsection{Soil Loss Tolerance Index for Crops (SLTI) and for Olive Groves (SLTIog)}

To correctly calibrate the SLTI, soil formation and degradation rates over time must be considered [26,58], along with the depth of degradable soils (i.e., the difference between soil depth and the useful soil depth of $20 \mathrm{~cm}$, which is assumed as a tillage layer and the dry bulk density [53]). Firstly, the weight of soil per unit area was estimated according to the Moreira-Madueño criterion [47]:

$$
\mathrm{W}=100 \times \text { Depth } \times \text { DBD, }
$$

where W: soil weight $\left(\mathrm{t} \mathrm{ha}^{-1}\right)$; Depth: soil depth (cm); DBD: dry bulk density $\left(\mathrm{gr} \mathrm{cm}^{-3}\right)$.

Based on the SLTI defined by Lombardi-Neto and Bertoni [25] and following the criteria set by Rodríguez Sousa et al. [31], some assumptions/limitations were made to adapt this index to crops. These assumptions are the following: (a) the time period in which a crop yield should be considered as constant is 100 years and (b) that soil erosion rates will be assumed to remain constant during the overall simulation experiment. The simulation times defined were: 1, 10, 25, 50, and 150 years, spanning from the immediate to the distant future. The SLTI was, therefore, calculated according to the following equation:

$$
\text { SLTI }=(\mathrm{W}-(\mathrm{E} \times \mathrm{Y}-\mathrm{R} \times \mathrm{Y})) \times 100^{-1},
$$

where SLTI: soil loss tolerance index for crops $\left(\mathrm{t} \mathrm{ha}^{-1}\right.$ year $\left.{ }^{-1}\right)$; $\mathrm{W}$ : weight of soil $\left(\mathrm{t} \mathrm{ha} \mathrm{a}^{-1}\right)$; E: soil erosion rate $\left(\mathrm{t} \mathrm{ha}^{-1}\right.$ year $\left.^{-1}\right)$; $\mathrm{R}$ : soil regeneration rate $\left(\mathrm{t} \mathrm{ha}^{-1}\right.$ year $\left.{ }^{-1}\right)$; $\mathrm{t}$ : simulation time (years); 100: time interval in years, in which yields must remain similar to current yields.

Soil regeneration, a variable that minimises soil loss due to erosion, was transformed from $\mathrm{mm}_{\text {year }}^{-1}$ to $\mathrm{tha}^{-1}$ year $^{-1}$ through the following equation:

$$
\mathrm{R}=\mathrm{R}_{\mathrm{mm}} \times \mathrm{DBD} \times 10,
$$


where $\mathrm{R}$ : soil regeneration ( $\mathrm{t} \mathrm{ha}^{-1}$ year $\left.^{-1}\right) ; \mathrm{R}_{\mathrm{mm}}$ : soil regeneration in $\mathrm{mm}_{\text {year }}{ }^{-1}$; DBD: dry bulk density $\left(\mathrm{gr} \mathrm{cm}^{-3}\right)$.

Despite the relevance of SLTI for agriculture, there is a need to devise more specific indices adapted to each type of crop. Thus, in the case of olive groves, a specific index exists that was published by Sousa et al. [31], defined as the Soil Loss Tolerance in olive groves (i.e., SLTIog). In order to establish a comparative study between the results in such research and the experiments described in this study, SLTIog was also computed for the Portuguese study area.

SLTIog incorporates the influence of key soil variables as mitigating agents for soil erosion processes. With the aim of excluding variables already considered as USLE factors, the main edaphic parameters that can mitigate soil erosion processes are the percentage of gravels by creating greater resistance to soil loss, porosity, contributing to the generation of edaphic aggregates, and organic matter, whose percentage is directly correlated to the increase in soil fertility $[59,60]$. Thus, firstly, it is necessary to standardise the values of each variable into a range between 0 and 1 in order to facilitate the comparison between the soil erosion mitigating potential across all management modes using a standardised erosion retardation factor (sERF). In order to correctly implement the SLTIog, the described edaphic variables were standardised according to the following MinMax scaler methodology [61]:

$$
\mathrm{sX}=(\mathrm{X}-\mathrm{X} \min ) \times(\mathrm{X} \max -\mathrm{X} \min )^{-1},
$$

where sX: standardised variable (dimensionless, from 0 to 1 ); $X$ : original value of the variable; $X \min$ and $X \max$ : minimum and maximum values of the original variable.

To obtain the final standardised values, a linear regression model was applied, including, as described in Equation (5), a standard soil erosion retardation factor, which will become 0 in the case that no soil erosion exists:

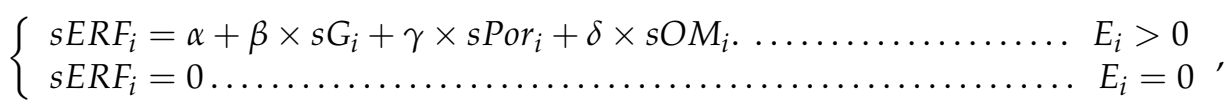

where $s E R F_{i}$ : standardised erosion retardation factor of erosion level $i\left(\mathrm{t} \mathrm{ha}^{-1} \mathrm{year}^{-1}\right)$; $\alpha$ : model intercept, dimensionless; $\beta, \gamma, \delta$ : coefficients of each independent variable, dimensionless; $s G_{i}$, $s \mathrm{Por}_{i}$ and $s O M_{i}$ : standardised gravels, porosity, and organic matter values of erosion level $i$.

For the incorporation of this factor in the final SLTIog equation, the standardisation of the $\mathrm{sERF}_{\mathrm{i}}$ factor was removed, resulting in the soil erosion retardation factor $\left(\mathrm{ERF}_{\mathrm{i}}\right)$ :

$$
\mathrm{ERF}_{\mathrm{i}}=\mathrm{sERF}_{\mathrm{i}} \times(\mathrm{sERFmax}-\mathrm{sERFmin})+\mathrm{sERFmin},
$$

where $\mathrm{ERF}_{\mathrm{i}}$ : erosion retardation factor of erosion level $\mathrm{i}\left(\mathrm{t} \mathrm{ha}^{-1}\right.$ year $\left.{ }^{-1}\right) ; \mathrm{SERF}_{\mathrm{i}}$ : standardised erosion retardation factor of erosion level $\mathrm{i}\left(\mathrm{t} \mathrm{ha}^{-1} \mathrm{year}^{-1}\right)$; sERFmax and sERFmin: maximum and minimum value of the standardised erosion retardation factor $\left(\mathrm{t} \mathrm{ha}^{-1}\right.$ year $\left.^{-1}\right)$.

In line with the criteria defined by Sousa et al. [31], it must be considered as a limitation of this model that the $\mathrm{ERF}_{\mathrm{i}}$ factor is only reliable for crops where soil variables are defined by the following non-standard value ranges: (a) gravels, between 0 and $40 \%$; (b) porosity, between 30 nd $90 \%$; and (c) a range of $0-4 \%$ for organic matter. According to these criteria, the SLTIog modified formulation is detailed as follows:

$$
\text { SLTIog }=\left(\left(W_{i}+R \times t\right)-\left(\left(E_{i} \times t\right)-\left(E R F_{i} \times t\right)\right) \times 100^{-1},\right.
$$

where SLTIog: soil loss tolerance index for olive groves $\left(\mathrm{t} \mathrm{ha}^{-1}\right.$ year $\left.{ }^{-1}\right) ; \mathrm{W}_{\mathrm{i}}$ : weight of soil for erosion level $i\left(t \mathrm{tha}^{-1}\right)$; $\mathrm{R}$ : regeneration soil rate $\left(\mathrm{t} \mathrm{ha}^{-1}\right.$ year $\left.^{-1}\right)$; $t$ : simulation time (years); $\mathrm{E}_{\mathrm{i}}$ : erosion of level i for the study area $\left(\mathrm{t} \mathrm{ha}^{-1} \mathrm{year}^{-1}\right) ; \mathrm{ERF}_{\mathrm{i}}$ : erosion retardation factor of erosion level $\mathrm{i}\left(\mathrm{t} \mathrm{ha}^{-1}\right.$ year $\left.^{-1}\right)$; 100: time period over which agricultural yields must be constant. 
All statistical analyses were carried out using RStudio software, using the car library and the agricolae, dplyr and PMCMRplus packages, considering a level of significance of $\alpha=0.05$ in all analyses [62].

\subsubsection{Soil Productivity Index (SPI)}

The SPI, as formulated by Duan et al. [27], was calibrated and adapted for each treatment and erosion level of the study area:

$$
\mathrm{SPI}_{\mathrm{i}}=\left(\mathrm{SM}_{\mathrm{i}} \times \mathrm{SpH}_{\mathrm{i}} \times \mathrm{SOM}_{\mathrm{i}} \times \mathrm{SK}_{\mathrm{i}} \times \mathrm{SCl}_{\mathrm{i}}\right) \times\left(\left(\left(\mathrm{W}_{\mathrm{i}}-\left(\left(\mathrm{E}_{\mathrm{i}}-\mathrm{R}\right)\right) \times \mathrm{t}\right)\right) \times\left(\mathrm{W}_{\text {maximum }}\right)^{-1},\right.
$$

where $\mathrm{SPI}_{\mathrm{i}}$ : soil productivity index in erosion level $\mathrm{i}$ (dimensionless, values between 0 and 1); $\mathrm{SM}_{\mathrm{i}}, \mathrm{SpH}_{\mathrm{i}}, \mathrm{SOM}_{\mathrm{i}}, \mathrm{SK}_{\mathrm{i}}, \mathrm{SCl}_{\mathrm{i}}$ : sufficiency values, in erosion level $\mathrm{i}$, of moisture, $\mathrm{pH}$, organic matter, potassium, and clays, respectively; $\mathrm{W}_{\mathrm{i}}$ : weight of soil in erosion level $\mathrm{i}$ $\left(\mathrm{t} \mathrm{ha}^{-1}\right.$ year $\left.^{-1}\right)$; $\mathrm{E}_{\mathrm{i}}$ : erosion rate $i\left(\mathrm{t} \mathrm{ha}^{-1}\right.$ year $\left.^{-1}\right)$; $\mathrm{R}$ : regeneration soil rate $\left(\mathrm{t} \mathrm{ha}^{-1}\right.$ year $\left.^{-1}\right)$; $\mathrm{t}$ : simulation time (years); Wmaximum: maximum soil weight among all treatments $\left(\mathrm{t} \mathrm{ha}^{-1}\right.$ year $\left.^{-1}\right)$.

To estimate this index (Equation (9)), the influence of the main variables linked to edaphic productivity (i.e., moisture, $\mathrm{pH}$, organic matter, potassium, and clays) must be considered $[40,63]$. To properly calibrate the SPI, the sufficiency values obtained for each variable in each sampled treatment must be calculated (i.e., dimensionless values rescaled between 0 and 1). These values were estimated from the empirical data obtained according to Duan et al. $[27,28,63]$. Thus, the higher the SPI value, the higher the soil productivity. In this sense, SPI values $<0.4$ correspond to a low soil productivity, values between 0.4 and 0.8 indicate an average soil productivity, and values $>0.8$ correspond to high soil productivity [28].

\section{Results}

\subsection{Soil Properties of the PDO Norte Alentejano}

Table 3 shows the results of the soil physicochemical variables estimated in the olive grove of the study area, with computed soil regeneration rates of $0.01 \mathrm{~mm}_{\text {year }}{ }^{-1}$. These results, including the standardised variables and sufficiency values, are of direct use in calibrating the agronomic indices.

In line with these results and assuming that deficit/drip irrigation is incorporated into the crop for all olive groves studied, a detrimental effect of erosion on soil conservation could be observed. In general, dry bulk density presents higher values in intensively managed olive groves, whereas lower soil densities are measured for traditional and integrated olive groves. This last parameter increased in the most eroded plots by $13.99 \%, 17.27 \%$, and $12.21 \%$ in the case of traditional, integrated, and intensive olive groves compared to plots where null soil erosion was detected. Soil depth decreased as soil erosion level increased, by $45.21 \%$ in the case of traditional olive groves, by $40.76 \%$ for integrated olive groves, and by $44.14 \%$ for intensive olive groves, with the latter occupying the shallowest soils across the PDO Norte Alentejano. These trends influence soil weight, with integrated olive groves generally presenting the highest values and with the maximum weight having been calculated at $16,870.20 \mathrm{tha}^{-1}$ in plots with null erosion. In contrast, the lowest values for soil weight were found in intensively managed olive grove plots.

Regarding soil texture, the study area was predominantly loam or sandy-loam, except for integrated plots with null or slight erosion, which showed a sandy-clay-loam texture. Taking into account that water runoff took place in fine soils, gravel content decreased in plots with high erosion, with soils having null gravels in intensive olive groves with moderate and severe erosive levels. Additionally, in this sense, the results indicated a slight decrease in the soil content of sand as the level of soil erosion increased due to a reduction of permeability and development of runoff processes. Similarly, the soil clay content also decreased with higher erosion processes that are aligned with agricultural intensification.

Structurally, the highest values of soil moisture were obtained for intensive olive groves. A decrease in porosity as soil erosion increased was observed, corresponding to 
values of $20.03 \%, 25.39 \%$, and $26.54 \%$, respectively, for traditional, integrated, and intensive olive groves, with the latter presenting the lowest values.

Table 3. Mean and standard error $(x \pm S E)$ values for each of the edaphic variables analysed (DBD: dry bulk density; D: soil depth; W: soil weight; Eq: equivalence $1 \mathrm{t}$ soil; G: gravel; S: sands; Sl: silts; Cl: clays; T: texture, where L: loam, SL: sandy-loam, SCL: sandy-clay-loam; P: porosity; M: moisture; OM: organic matter; K: potassium). Their units are specified according to the different management options (i.e., traditional, integrated, and intensive) and degrees of erosion (i.e., null, slight, moderate, and severe) defined for the olive grove in the study area. The standardised values for gravels, porosity, and organic matter (sG, sP, sOM), and the sufficiency values for moisture, $\mathrm{pH}$, organic matter, potassium, and clays (i.e., $\mathrm{SM}$, $\mathrm{SpH}, \mathrm{SOM}, \mathrm{SK}, \mathrm{SCl})$, used for the estimation of different agronomic indices, are also attached.

\begin{tabular}{|c|c|c|c|c|c|c|c|c|c|c|c|c|}
\hline \multirow{2}{*}{$\begin{array}{c}\text { Variable } \\
\text { (Unit) }\end{array}$} & \multicolumn{4}{|c|}{ Traditional Olive Groves } & \multicolumn{4}{|c|}{ Integrated Olive Groves } & \multicolumn{4}{|c|}{ Intensive Olive Groves } \\
\hline & Null & Slight & Moderate & Severe & Null & Slight & Moderate & Severe & Null & Slight & Moderate & Severe \\
\hline $\begin{array}{c}\mathrm{DBD} \\
\left(\mathrm{gr} \mathrm{cm}^{-3}\right)\end{array}$ & $\begin{array}{c}1.23 \\
\pm 0.01\end{array}$ & $\begin{array}{c}1.32 \\
\pm 0.01\end{array}$ & $\begin{array}{c}1.38 \\
\pm 0.01\end{array}$ & $\begin{array}{c}1.43 \\
\pm 0.01\end{array}$ & $\begin{array}{c}1.15 \\
\pm 0.03\end{array}$ & $\begin{array}{c}1.30 \\
\pm 0.02\end{array}$ & $\begin{array}{c}1.34 \\
\pm 0.01\end{array}$ & $\begin{array}{c}1.39 \\
\pm 0.02\end{array}$ & $\begin{array}{c}1.51 \\
\pm 0.01\end{array}$ & $\begin{array}{c}1.59 \\
\pm 0.01\end{array}$ & $\begin{array}{c}1.66 \\
\pm 0.01\end{array}$ & $\begin{array}{c}1.72 \\
\pm 0.01\end{array}$ \\
\hline $\mathrm{D}(\mathrm{cm})$ & $\begin{array}{l}126.38 \\
\pm 2.36\end{array}$ & $\begin{array}{l}109.18 \\
\pm 3.06\end{array}$ & $\begin{array}{c}90.47 \\
\pm 1.06\end{array}$ & $\begin{array}{c}69.24 \\
\pm 1.26\end{array}$ & $\begin{array}{l}146.75 \\
\pm 1.13\end{array}$ & $\begin{array}{l}124.79 \\
\pm 1.91\end{array}$ & $\begin{array}{l}101.95 \\
\pm 1.36\end{array}$ & $\begin{array}{c}86.93 \\
\pm 0.79\end{array}$ & $\begin{array}{l}77.43 \\
\pm 2.14\end{array}$ & $\begin{array}{c}62.20 \\
\pm 1.03\end{array}$ & $\begin{array}{l}55.16 \\
\pm 2.28\end{array}$ & $\begin{array}{c}43.25 \\
\pm 1.87\end{array}$ \\
\hline $\begin{array}{c}\mathrm{W} \\
\left(\mathrm{t} \mathrm{ha}^{-1}\right)\end{array}$ & $\begin{array}{l}15,571.45 \\
\pm 299.65\end{array}$ & $\begin{array}{l}14,476.98 \\
\pm 530.10\end{array}$ & $\begin{array}{l}12,461.40 \\
\pm 128.41\end{array}$ & $\begin{array}{c}9929.37 \\
\pm 203.79\end{array}$ & $\begin{array}{l}16,870.20 \\
\pm 318.43\end{array}$ & $\begin{array}{l}16,201.45 \\
\pm 452.19\end{array}$ & $\begin{array}{l}13,689.69 \\
\pm 260.69\end{array}$ & $\begin{array}{c}12,057.50 \\
\pm 113.98\end{array}$ & $\begin{array}{l}11,733.36 \\
\pm 377.21\end{array}$ & $\begin{array}{c}9887.70 \\
\pm 142.09\end{array}$ & $\begin{array}{c}9143.84 \\
\pm 381.23\end{array}$ & $\begin{array}{c}7446.39 \\
\pm 301.60\end{array}$ \\
\hline $\mathrm{Eq}(\mathrm{mm})$ & $\begin{array}{c}0.08 \\
\pm 0.01\end{array}$ & $\begin{array}{c}0.07 \\
\pm 0.01\end{array}$ & $\begin{array}{c}0.07 \\
\pm 0.01\end{array}$ & $\begin{array}{c}0.07 \\
\pm 0.01\end{array}$ & $\begin{array}{c}0.09 \\
\pm 0.01\end{array}$ & $\begin{array}{c}0.08 \\
\pm 0.01\end{array}$ & $\begin{array}{c}0.07 \\
\pm 0.01\end{array}$ & $\begin{array}{c}0.07 \\
\pm 0.01\end{array}$ & $\begin{array}{c}0.07 \\
\pm 0.01\end{array}$ & $\begin{array}{c}0.06 \\
\pm 0.01\end{array}$ & $\begin{array}{c}0.06 \\
\pm 0.01\end{array}$ & $\begin{array}{c}0.06 \\
\pm 0.01\end{array}$ \\
\hline G (\%) & $\begin{array}{c}9.34 \\
\pm 0.42\end{array}$ & $\begin{array}{c}8.03 \\
\pm 0.75\end{array}$ & $\begin{array}{c}5.00 \\
\pm 0.30\end{array}$ & $\begin{array}{c}2.74 \\
\pm 0.35\end{array}$ & $\begin{array}{c}11.71 \\
\pm 0.96\end{array}$ & $\begin{array}{c}10.59 \\
\pm 0.16\end{array}$ & $\begin{array}{c}7.66 \\
\pm 0.43\end{array}$ & $\begin{array}{c}6.51 \\
\pm 0.20\end{array}$ & $\begin{array}{c}3.72 \\
\pm 0.18\end{array}$ & $\begin{array}{c}1.36 \\
\pm 0.07\end{array}$ & $\begin{array}{c}0.00 \\
\pm 0.00\end{array}$ & $\begin{array}{c}0.00 \\
\pm 0.00\end{array}$ \\
\hline $\mathrm{S}(\%)$ & $\begin{array}{l}59.65 \\
\pm 1.10\end{array}$ & $\begin{array}{c}53.34 \\
\pm 1.83\end{array}$ & $\begin{array}{l}56.48 \\
\pm 2.74\end{array}$ & $\begin{array}{l}52.46 \\
\pm 2.22\end{array}$ & $\begin{array}{c}66.07 \\
\pm 1.82\end{array}$ & $\begin{array}{c}58.13 \\
\pm 3.39\end{array}$ & $\begin{array}{l}54.56 \\
\pm 1.05\end{array}$ & $\begin{array}{l}48.24 \\
\pm 1.32\end{array}$ & $\begin{array}{c}41.71 \\
\pm 1.87\end{array}$ & $\begin{array}{l}45.85 \\
\pm 1.16\end{array}$ & $\begin{array}{c}46.61 \\
\pm 1.86\end{array}$ & $\begin{array}{l}49.20 \\
\pm 0.74\end{array}$ \\
\hline $\mathrm{Sl}(\%)$ & $\begin{array}{c}22.17 \\
\pm 1.91\end{array}$ & $\begin{array}{c}29.73 \\
\pm 0.95\end{array}$ & $\begin{array}{l}32.45 \\
\pm 2.20\end{array}$ & $\begin{array}{c}38.89 \\
\pm 1.74\end{array}$ & $\begin{array}{c}11.97 \\
\pm 2.40\end{array}$ & $\begin{array}{c}18.39 \\
\pm 2.24\end{array}$ & $\begin{array}{c}26.37 \\
\pm 2.04\end{array}$ & $\begin{array}{c}39.74 \\
\pm 1.56\end{array}$ & $\begin{array}{l}44.35 \\
\pm 1.57\end{array}$ & $\begin{array}{c}38.56 \\
\pm 0.68\end{array}$ & $\begin{array}{c}39.85 \\
\pm 0.90\end{array}$ & $\begin{array}{l}45.60 \\
\pm 1.02\end{array}$ \\
\hline $\mathrm{Cl}(\%)$ & $\begin{array}{c}18.18 \\
\pm 0.89\end{array}$ & $\begin{array}{c}16.93 \\
\pm 1.72\end{array}$ & $\begin{array}{l}11.07 \\
\pm 2.16\end{array}$ & $\begin{array}{c}8.65 \\
\pm 0.58\end{array}$ & $\begin{array}{c}21.96 \\
\pm 0.90\end{array}$ & $\begin{array}{l}23.48 \\
\pm 2.20\end{array}$ & $\begin{array}{l}19.07 \\
\pm 1.50\end{array}$ & $\begin{array}{c}12.02 \\
\pm 1.05\end{array}$ & $\begin{array}{c}13.93 \\
\pm 2.31\end{array}$ & $\begin{array}{c}15.59 \\
\pm 0.77\end{array}$ & $\begin{array}{c}13.53 \\
\pm 1.85\end{array}$ & $\begin{array}{c}5.20 \\
\pm 1.64\end{array}$ \\
\hline $\mathrm{T}$ & SL & SL & SL & SL & SCL & SCL & SL & $\mathrm{L}$ & $\mathrm{L}$ & $\mathrm{L}$ & $\mathrm{L}$ & SL \\
\hline $\mathrm{P}(\%)$ & $\begin{array}{c}60.67 \\
\pm 1.04\end{array}$ & $\begin{array}{l}55.33 \\
\pm 0.05\end{array}$ & $\begin{array}{l}52.55 \\
\pm 0.66\end{array}$ & $\begin{array}{l}48.52 \\
\pm 0.75\end{array}$ & $\begin{array}{c}68.96 \\
\pm 0.36\end{array}$ & $\begin{array}{c}64.97 \\
\pm 1.29\end{array}$ & $\begin{array}{l}60.39 \\
\pm 0.21\end{array}$ & $\begin{array}{l}51.45 \\
\pm 3.59\end{array}$ & $\begin{array}{l}47.21 \\
\pm 0.72\end{array}$ & $\begin{array}{l}40.07 \\
\pm 0.69\end{array}$ & $\begin{array}{l}38.53 \\
\pm 0.97\end{array}$ & $\begin{array}{l}34.68 \\
\pm 1.31\end{array}$ \\
\hline $\mathrm{M}(\%)$ & $\begin{array}{l}32.95 \\
\pm 1.70\end{array}$ & $\begin{array}{c}40.31 \\
\pm 0.31\end{array}$ & $\begin{array}{l}29.08 \\
\pm 5.05\end{array}$ & $\begin{array}{c}36.63 \\
\pm 6.39\end{array}$ & $\begin{array}{l}27.09 \\
\pm 1.00\end{array}$ & $\begin{array}{l}29.77 \\
\pm 2.31\end{array}$ & $\begin{array}{l}25.01 \\
\pm 2.54\end{array}$ & $\begin{array}{l}43.00 \\
\pm 2.41\end{array}$ & $\begin{array}{l}44.32 \\
\pm 0.46\end{array}$ & $\begin{array}{l}37.60 \\
\pm 0.39\end{array}$ & $\begin{array}{l}35.74 \\
\pm 0.89\end{array}$ & $\begin{array}{l}30.99 \\
\pm 0.61\end{array}$ \\
\hline $\mathrm{pH}(-)$ & $\begin{array}{c}8.06 \\
\pm 0.05 \\
\end{array}$ & $\begin{array}{c}7.89 \\
\pm 0.01 \\
\end{array}$ & $\begin{array}{c}7.69 \\
\pm 0.03 \\
\end{array}$ & $\begin{array}{c}7.49 \\
\pm 0.01 \\
\end{array}$ & $\begin{array}{c}8.28 \\
\pm 0.01 \\
\end{array}$ & $\begin{array}{c}8.14 \\
\pm 0.01 \\
\end{array}$ & $\begin{array}{c}7.91 \\
\pm 0.04 \\
\end{array}$ & $\begin{array}{c}7.68 \\
\pm 0.03 \\
\end{array}$ & $\begin{array}{c}7.81 \\
\pm 0.02 \\
\end{array}$ & $\begin{array}{c}7.64 \\
\pm 0.01 \\
\end{array}$ & $\begin{array}{c}7.49 \\
\pm 0.02 \\
\end{array}$ & $\begin{array}{c}7.22 \\
\pm 0.02 \\
\end{array}$ \\
\hline OM (\%) & $\begin{array}{c}3.83 \\
\pm 0.02\end{array}$ & $\begin{array}{c}3.24 \\
\pm 0.09\end{array}$ & $\begin{array}{c}2.96 \\
\pm 0.15\end{array}$ & $\begin{array}{c}2.30 \\
\pm 0.05\end{array}$ & $\begin{array}{c}4.30 \\
\pm 0.18\end{array}$ & $\begin{array}{c}3.70 \\
\pm 0.09\end{array}$ & $\begin{array}{c}3.27 \\
\pm 0.05\end{array}$ & $\begin{array}{c}2.90 \\
\pm 0.08\end{array}$ & $\begin{array}{c}2.61 \\
\pm 0.02\end{array}$ & $\begin{array}{c}2.00 \\
\pm 0.05\end{array}$ & $\begin{array}{c}1.29 \\
\pm 0.03\end{array}$ & $\begin{array}{c}0.90 \\
\pm 0.01\end{array}$ \\
\hline $\begin{array}{c}\mathrm{K} \\
\left(\mathrm{mg} \mathrm{kg}^{-1}\right)\end{array}$ & $\begin{array}{l}100.20 \\
\pm 1.01 \\
\end{array}$ & $\begin{array}{c}84.15 \\
\pm 1.48 \\
\end{array}$ & $\begin{array}{l}78.18 \\
\pm 0.73 \\
\end{array}$ & $\begin{array}{l}52.81 \\
\pm 1.10 \\
\end{array}$ & $\begin{array}{l}119.21 \\
\pm 3.82 \\
\end{array}$ & $\begin{array}{l}101.06 \\
\pm 1.93 \\
\end{array}$ & $\begin{array}{l}82.01 \\
\pm 2.02 \\
\end{array}$ & $\begin{array}{l}66.30 \\
\pm 1.85 \\
\end{array}$ & $\begin{array}{l}129.98 \\
\pm 4.05 \\
\end{array}$ & $\begin{array}{l}110.58 \\
\pm 3.41 \\
\end{array}$ & $\begin{array}{l}104.38 \\
\pm 1.39 \\
\end{array}$ & $\begin{array}{c}85.04 \\
\pm 3.91 \\
\end{array}$ \\
\hline sG & 0.80 & 0.69 & 0.43 & 0.23 & 1.00 & 0.90 & 0.65 & 0.56 & 0.32 & 0.12 & 0.00 & 0.00 \\
\hline $\mathrm{sP}$ & 0.76 & 0.60 & 0.52 & 0.40 & 1.00 & 0.88 & 0.75 & 0.49 & 0.37 & 0.16 & 0.11 & 0.00 \\
\hline $\mathrm{sOM}$ & 0.86 & 0.69 & 0.61 & 0.41 & 1.00 & 0.82 & 0.70 & 0.59 & 0.50 & 0.32 & 0.11 & 0.00 \\
\hline SM & 1.00 & 1.00 & 1.00 & 1.00 & 1.00 & 1.00 & 1.00 & 1.00 & 1.00 & 1.00 & 1.00 & 1.00 \\
\hline $\mathrm{SpH}$ & 0.75 & 0.77 & 0.80 & 0.84 & 0.75 & 0.75 & 0.77 & 0.80 & 0.78 & 0.81 & 0.84 & 0.88 \\
\hline SOM & 0.96 & 0.81 & 0.74 & 0.58 & 1.00 & 0.93 & 0.82 & 0.73 & 0.65 & 0.50 & 0.32 & 0.23 \\
\hline SK & 0.59 & 0.50 & 0.46 & 0.31 & 0.70 & 0.59 & 0.48 & 0.39 & 0.76 & 0.65 & 0.61 & 0.50 \\
\hline $\mathrm{SCl}$ & 0.91 & 0.85 & 0.55 & 0.43 & 1.00 & 1.00 & 0.95 & 0.60 & 0.70 & 0.78 & 0.68 & 0.26 \\
\hline
\end{tabular}

Soil $\mathrm{pH}$ in Portuguese farms was generally slightly basic, with values above 7.00 for all types of olive groves examined. However, a mild acidification was observed in the most eroded and intensive olive plots. Organic matter losses of up to $39.95 \%, 32.56 \%$, and $65.52 \%$ were also measured in traditional, integrated, and intensive olive groves, respectively. This was largely driven by soil erosion processes, with intensive agriculture showing the lowest overall carbon content. Edaphic potassium concentration, although decreasing with soil erosion (i.e., up to $47.30 \%$ ), showed lower values for traditional and integrated olive groves than in intensive ones. Regarding to the estimated sufficiency values, high levels of soil moisture content are the norm at the sub-regional level, along with high $\mathrm{pH}$ sufficiency values. In contrast, the sufficiency of organic matter and clays in soils presented mediumhigh values in traditional and integrated olive groves, the latter being the treatment with the highest levels measured under null erosion, whilst this value decreased notably in 
olive groves under intensive management and with moderate to severe erosion. Finally, sufficiency for potassium was higher in intensively managed olive plots.

\subsection{Soil Loss Tolerance and Soil Productivity in the PDO Norte Alentejano}

In advance to showing the results of the two agronomic indices for the PDO Norte Alentejano, Table 4 shows the statistical results obtained for the multiple linear regression calculation on the basis of which the $S E R F$ factor was developed. These results show an $\mathrm{R}^{2}=51.5 \%$, which can be considered as highly significant (i.e., $p$-value $<0.001^{* * *}$ ).

Table 4. Coefficient, standard error, and significance for each variable considered in the multiple linear regression to define the standardised erosion retardation factor $(s E R F)$. Significance values are as follows: not significant $(>0.05)$, significant $\left(<0.05^{*}\right)$, very significant $\left(<0.01^{* *}\right)$, highly significant $\left(<0.001^{* * *}\right)$.

\begin{tabular}{|c|c|c|c|c|}
\hline \multirow[b]{3}{*}{ Coefficient } & \multirow{2}{*}{ Intercept } & \multicolumn{3}{|c|}{ Normalised Variables } \\
\hline & & Gravel & Porosity & Organic Matter \\
\hline & 0.842 & 0.024 & 1.342 & -2.186 \\
\hline Standard error & 0.089 & 0.05 & 0.569 & 0.510 \\
\hline Significance & $<0.001^{* * *}$ & $<0.05^{*}$ & $<0.05^{*}$ & $<0.001^{* * *}$ \\
\hline
\end{tabular}

Based on this calibration, the independent variables showed a significant influence as mitigating agents of soil erosion. Agronomic indices, including the specific model designed for olive groves, were then executed for all types of crops and treatments (i.e., SLTI, SLTIog, SPI). The results are shown in Table 5.

Table 5. Soil Loss Tolerance Index (SLTI), Soil Loss Tolerance Index for olive groves (SLTIog), and Soil Productivity Index (SPI) for the PDO Norte Alentejano, taking into account the implementation of drip irrigation in all treatments. If in any of the simulations the value of any of the indices is zero (0), it is considered to be an unsustainable situation (US).

\begin{tabular}{|c|c|c|c|c|c|c|c|}
\hline \multirow{2}{*}{$\begin{array}{l}\text { Olive Grove } \\
\text { Management }\end{array}$} & \multirow{2}{*}{$\begin{array}{c}\text { Erosion } \\
\text { t ha }^{-1} \text { year }^{-1}\end{array}$} & \multirow{2}{*}{$\begin{array}{c}\text { Simulation } \\
\text { Timescales } \\
\text { years }\end{array}$} & \multicolumn{2}{|c|}{ SLTI } & \multicolumn{2}{|c|}{ SLTIog } & \multirow{2}{*}{ SPI } \\
\hline & & & t ha ${ }^{-1}$ year $^{-1}$ & mm year $^{-1}$ & tha ${ }^{-1}$ year $^{-1}$ & mm year $^{-1}$ & \\
\hline \multirow{20}{*}{ Traditional } & \multirow{5}{*}{0.00} & 1 & 130.85 & 10.47 & 130.85 & 10.47 & 0.35 \\
\hline & & 10 & 130.86 & 10.47 & 130.86 & 10.47 & 0.35 \\
\hline & & 25 & 130.88 & 10.47 & 130.88 & 10.47 & 0.35 \\
\hline & & 50 & 130.91 & 10.47 & 130.91 & 10.47 & 0.35 \\
\hline & & 150 & 131.03 & 10.48 & 131.03 & 10.48 & 0.35 \\
\hline & \multirow{5}{*}{2.24} & 1 & 117.70 & 8.24 & 117.70 & 8.24 & 0.21 \\
\hline & & 10 & 117.51 & 8.23 & 117.52 & 8.23 & 0.21 \\
\hline & & 25 & 117.19 & 8.20 & 117.22 & 8.21 & 0.21 \\
\hline & & 50 & 116.66 & 8.17 & 116.73 & 8.17 & 0.21 \\
\hline & & 150 & 114.56 & 8.02 & 114.76 & 8.03 & 0.20 \\
\hline & \multirow{5}{*}{11.37} & 1 & 97.14 & 6.80 & 97.14 & 6.80 & 0.10 \\
\hline & & 10 & 96.13 & 6.73 & 96.14 & 6.73 & 0.10 \\
\hline & & 25 & 94.44 & 6.61 & 94.49 & 6.61 & 0.10 \\
\hline & & 50 & 91.63 & 6.41 & 91.73 & 6.42 & 0.09 \\
\hline & & 150 & 80.40 & 5.63 & 80.69 & 5.65 & 0.08 \\
\hline & \multirow{5}{*}{27.03} & 1 & 70.14 & 4.91 & 70.15 & 4.91 & 0.03 \\
\hline & & 10 & 67.72 & 4.74 & 67.77 & 4.74 & 0.03 \\
\hline & & 25 & 63.69 & 4.46 & 63.79 & 4.47 & 0.03 \\
\hline & & 50 & 56.97 & 3.99 & 57.18 & 4.00 & 0.03 \\
\hline & & 150 & 30.08 & 2.11 & 30.70 & 2.15 & 0.01 \\
\hline
\end{tabular}


Table 5. Cont.

\begin{tabular}{|c|c|c|c|c|c|c|c|}
\hline \multirow{2}{*}{$\begin{array}{l}\text { Olive Grove } \\
\text { Management }\end{array}$} & \multirow{2}{*}{$\begin{array}{c}\text { Erosion } \\
\text { t ha }^{-1} \text { year }^{-1}\end{array}$} & \multirow{2}{*}{$\begin{array}{c}\text { Simulation } \\
\text { Timescales } \\
\text { years }\end{array}$} & \multicolumn{2}{|c|}{ SLTI } & \multicolumn{2}{|c|}{ SLTIog } & \multirow{2}{*}{ SPI } \\
\hline & & & tha t $^{-1}$ year $^{-1}$ & mm year $^{-1}$ & tha hear $^{-1}$ ye $^{-1}$ & mm year $^{-1}$ & \\
\hline \multirow{20}{*}{ Integrated } & \multirow{5}{*}{0.00} & 1 & 145.76 & 13.12 & 145.76 & 13.12 & 0.53 \\
\hline & & 10 & 145.77 & 13.12 & 145.77 & 13.12 & 0.53 \\
\hline & & 25 & 145.79 & 13.12 & 145.79 & 13.12 & 0.53 \\
\hline & & 50 & 145.82 & 13.12 & 145.82 & 13.12 & 0.53 \\
\hline & & 150 & 145.94 & 13.13 & 145.94 & 13.13 & 0.53 \\
\hline & \multirow{5}{*}{1.47} & 1 & 136.21 & 10.90 & 136.22 & 10.90 & 0.39 \\
\hline & & 10 & 136.09 & 10.89 & 136.11 & 10.89 & 0.39 \\
\hline & & 25 & 135.89 & 10.87 & 135.94 & 10.88 & 0.38 \\
\hline & & 50 & 135.56 & 10.84 & 135.66 & 10.85 & 0.38 \\
\hline & & 150 & 134.22 & 10.74 & 134.53 & 10.76 & 0.38 \\
\hline & \multirow{5}{*}{7.81} & 1 & 109.74 & 7.68 & 109.74 & 7.68 & 0.22 \\
\hline & & 10 & 109.05 & 7.63 & 109.07 & 7.64 & 0.22 \\
\hline & & 25 & 107.89 & 7.55 & 107.97 & 7.56 & 0.21 \\
\hline & & 50 & 105.98 & 7.42 & 106.12 & 7.43 & 0.21 \\
\hline & & 150 & 98.30 & 6.88 & 98.73 & 6.91 & 0.19 \\
\hline & \multirow{5}{*}{20.29} & 1 & 92.83 & 6.50 & 92.83 & 6.50 & 0.09 \\
\hline & & 10 & 91.02 & 6.37 & 91.04 & 6.37 & 0.09 \\
\hline & & 25 & 87.99 & 6.16 & 88.04 & 6.16 & 0.08 \\
\hline & & 50 & 82.96 & 5.81 & 83.05 & 5.81 & 0.08 \\
\hline & & 150 & 62.81 & 4.40 & 63.09 & 4.42 & 0.06 \\
\hline \multirow{20}{*}{ Intensive } & \multirow{5}{*}{0.00} & 1 & 86.72 & 6.07 & 86.72 & 6.07 & 0.16 \\
\hline & & 10 & 86.73 & 6.07 & 86.73 & 6.07 & 0.16 \\
\hline & & 25 & 86.76 & 6.07 & 86.76 & 6.07 & 0.16 \\
\hline & & 50 & 86.79 & 6.08 & 86.79 & 6.08 & 0.16 \\
\hline & & 150 & 86.95 & 6.09 & 86.95 & 6.09 & 0.16 \\
\hline & \multirow{5}{*}{3.93} & 1 & 67.06 & 4.02 & 67.06 & 4.02 & 0.09 \\
\hline & & 10 & 66.72 & 4.00 & 66.75 & 4.01 & 0.09 \\
\hline & & 25 & 66.16 & 3.97 & 66.23 & 3.97 & 0.09 \\
\hline & & 50 & 65.21 & 3.91 & 65.36 & 3.92 & 0.09 \\
\hline & & 150 & 61.44 & 3.69 & 61.88 & 3.71 & 0.09 \\
\hline & \multirow{5}{*}{12.38} & 1 & 58.24 & 3.49 & 58.25 & 3.49 & 0.04 \\
\hline & & 10 & 57.14 & 3.43 & 57.21 & 3.43 & 0.04 \\
\hline & & 25 & 55.31 & 3.32 & 55.47 & 3.33 & 0.04 \\
\hline & & 50 & 52.26 & 3.14 & 52.57 & 3.15 & 0.04 \\
\hline & & 150 & 40.04 & 2.40 & 40.98 & 2.46 & 0.03 \\
\hline & \multirow{5}{*}{30.05} & 1 & 39.69 & 2.38 & 39.70 & 2.38 & 0.01 \\
\hline & & 10 & 37.00 & 2.22 & 37.07 & 2.22 & 0.01 \\
\hline & & 25 & 32.52 & 1.95 & 32.70 & 1.96 & 0.01 \\
\hline & & 50 & 25.05 & 1.50 & 25.40 & 1.52 & 0.01 \\
\hline & & 150 & US & US & US & US & US \\
\hline
\end{tabular}

A negative effect of erosion on soil loss tolerance became evident for all types of olive groves evaluated, with the latter decreasing with higher soil erosion rates and longer simulation timescales. It should be noted that the increase in soil loss tolerance detected in plots without any corrective measures implemented is reflective of a simple mathematical trend, whereby in the absence of significant long-term erosion processes, soil regeneration triggers the formation of a greater amount of soil over time. The general results for SLTI showed decreases of up to $46.40 \%, 36.31 \%$, and $54.23 \%$ for traditional, integrated, and intensive olive groves for 1-year forecasts and of $77.04 \%$ and $56.96 \%$ for traditional and integrated olive groves in 150-year projections. In line with the SLTI, intensive olive groves were detected to become not sustainable from soil and agronomical perspectives in the 
long term. The results for SLTIog were very similar, also showing decreases in soil loss tolerance as a function of erosion processes. In general, integrated olive groves presented the highest values across all the estimated indices, while the intensive ones showed the lowest long-term sustainability rates. Although there were no significant differences encountered between the results of the SLTI and SLTIog indices (i.e., $p$-value $>0.05$ ), the index implemented specifically for olive groves showed slightly higher tolerance values as plot-scale soil erosion rates and projected timescales increased (i.e., a maximum difference of $2.02 \%$ and $0.45 \%$ between SLTIog and SLTI was detected for 150-year projections on severely eroded soils in traditional and integrated olive groves, respectively).

According to the SLTI and SLTIog indices, in the absence of soil erosion processes, integrated olive groves showed $10.23 \%$ and $40.51 \%$ more soil loss tolerance than traditional and intensive ones for the case of imminent timescale projections (i.e., 1 year), decreasing, respectively, to $10.22 \%$ and $40.40 \%$ for 150 -year simulations. However, under severe erosion conditions, integrated olive groves continued to show $(24.44 \%$ and $57.25 \%)$ higher results than both traditional and intensive plots for 1-year simulations, and $52.11 \%$ in the case of traditional olive groves for distant timescale simulations (i.e., 150 years). This makes the intensive plots with severe erosion unsustainable under such timescale projections. In addition, soil erosion processes were also found to have a negative influence on soil productivity, causing respective declines of $91.43 \%, 76.92 \%$, and $93.75 \%$ in the cases of traditional, integrated, and intensive olive groves under 1-year timescale projections. These decreases went up to $97.14 \%$ and $84.21 \%$ for the traditional and integrated olive groves when they were considered under a 150-year timescale simulation. Thus, soil environment was unproductive for longer-term projections in the intensive olive groves. Finally, it is important to highlight how all of the olive grove management typologies considered showed low soil productivity rates (i.e., $<0.4$ ), except for the traditional and integrated olive grove plots without soil erosion processes, the latter of which were found to be the most productive with an SPI of 0.53 .

\subsection{Previous Results for the PDO Estepa}

Results published for the PDO Estepa are briefly summarised in Figure 4. In this area, the linear regression model showed an $\mathrm{R}^{2}>90 \%$, being a highly significant model $\left(p\right.$-value $\left.<0.001^{* * *}\right)$. Thus, the generally sustainable character of the olive grove in this region becomes largely evident, except for the case of irrigated crops with severe erosion rates in long-term timescale simulations (i.e., 150 years), calculated according to the SLTI.

The level of soil erosion and of irrigation were thus the key factors contributing to minimising soil loss tolerance. The results suggest an inverse relationship between soil erosion and irrigation with respect to the level of tolerance to soil loss in all olive groves. In general terms, the results showed the sustainability of olive groves in Estepa region, and through the SLTIog, even the olive groves with severe erosion and irrigation may be viable at 150 years. The soil loss tolerance decreased from $135.09 \mathrm{t} \mathrm{ha}^{-1}$ year $^{-1}$ to 65.56-65.57 $\mathrm{t} \mathrm{ha}^{-1}$ year $^{-1}$ in the integrated rainfed crops due to the erosion processes. The SLTI and SLTIog showed decreases of $20-25 \%$ in irrigated farms compared to the rainfed olive groves with equivalent erosion levels. For the organic olive groves, a slight increase was observed in soil loss tolerance regarding the integrated management (i.e., from $135.09 \mathrm{t} \mathrm{ha}^{-1}$ year $^{-1}$ to $140.73 \mathrm{t} \mathrm{ha}^{-1}$ year ${ }^{-1}$ in plots with null erosion, and from $107.33 \mathrm{t} \mathrm{ha}^{-1}$ year $^{-1}$ to $113.63-113.64 \mathrm{t} \mathrm{ha}^{-1}$ year $^{-1}$ in plots with moderate erosion).

This study area is characterised by low-medium values of soil productivity, the most productive plots being the organic ones with null erosion rates, which presented values around 0.45 . The influence of soil erosion resulted in decreases in the productivity ranging between 0.19 in the case of integrated rainfed olive groves with null erosion, and up to $0.02-0.01$ in plots with severe erosion. In the case of plots with moderate erosion rates, the presence of irrigation led to a decrease of $40 \%$ in the SPI. 

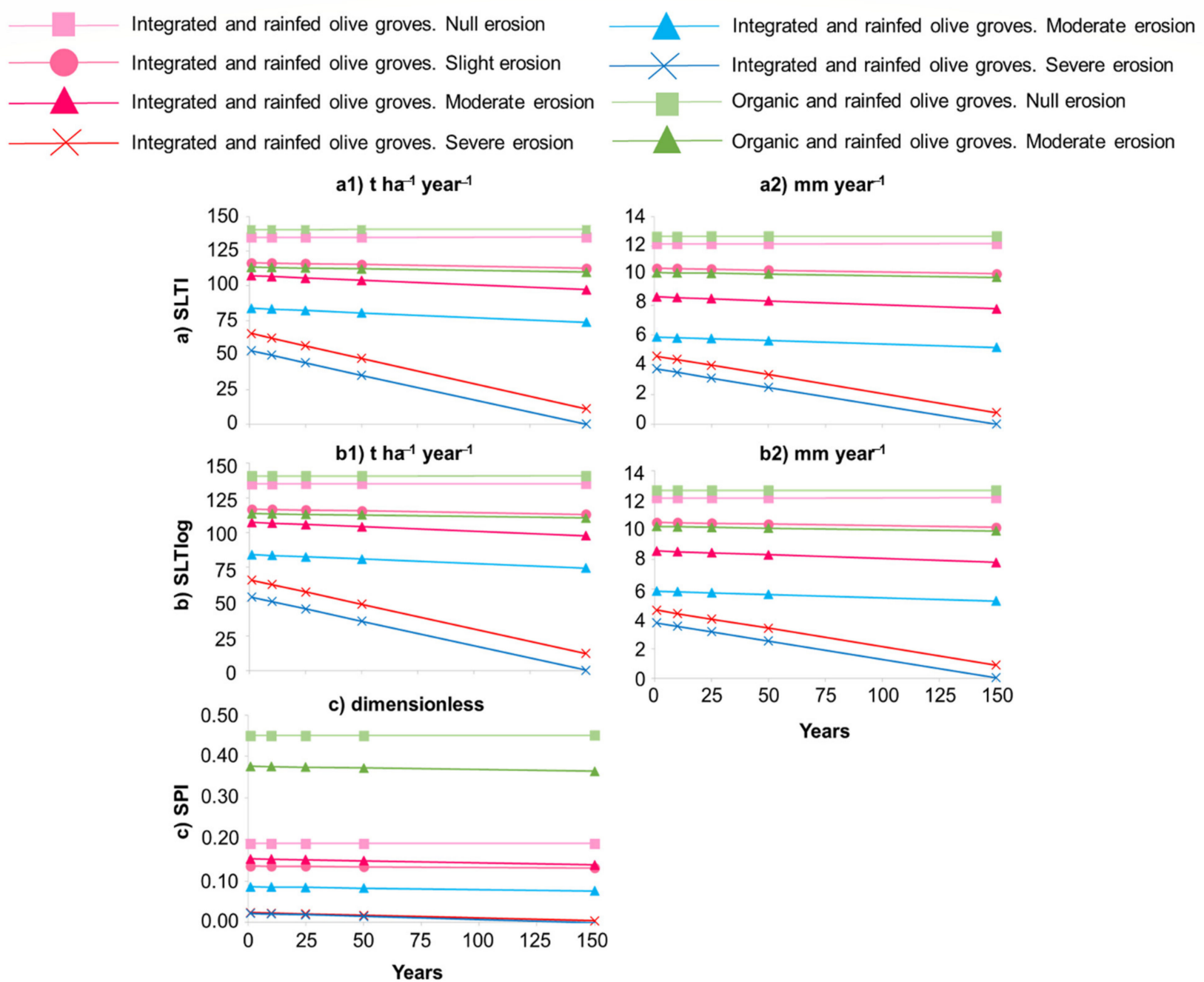

Years

Figure 4. SLTI ( $\mathrm{t} \mathrm{ha}^{-1} \operatorname{year}^{-1}$ (a1) and mm year ${ }^{-1}$ (a2)), SLTIog ( $\mathrm{t} \mathrm{ha}{ }^{-1}$ year $^{-1}$ (b1) and mm year ${ }^{-1}$ (b2)), and SPI (c, dimensionless) indices for the olive grove types and related soil erosion levels calculated in the PDO Estepa. Each mark on the trendlines represents the timescale projections considered, respectively, corresponding to 1, 10, 25, 50, and 150 years.

\section{Discussion}

\subsection{Influence of Erosion on the Soil Environment of Portuguese Olive Groves}

Although the magnitude of soil erosion depends on the agricultural practices carried out on crops and can be mitigated through the correct use and management of the soil environment (i.e., multifunctional agricultural practices), it also depends intrinsically on geological and morphological factors of the territory [30,51]. In this sense, the slope of the crops is a key factor in determining soil loss, as the steeper the slope, the greater the risk of runoff and entrainment of soil materials, which can lead to the formation of gullies [59,64]. Several studies have shown how integrated olive groves combining the controlled supply of chemical fertilisers and deficit/drip irrigation, with the implementation of partial plant covers, minimises the magnitude of erosion processes, thereby mitigating surface runoff and reducing the decline in agricultural productivity due to loss of soil fertility $[30,51,65,66]$. On the other hand, intensively management models clearly trigger an increase in short-term production rates that are, in the case of olive oil, aligned with the current increase in market demand. Nonetheless, they also result in increased environmental impacts that potentially hamper the sustainability of crops over longer timescales [21,67]. Despite the relatively short history of olive intensification processes in Portugal, the results show a slight edaphic degradation. In this sense, an increase in dry bulk density was observed for intensive olive groves affected by higher erosion rates due to the characteristic tillage practices of this 
management, such as the indiscriminate use of agricultural machinery $[20,68-70]$. On the other hand, integrated crops, where plant covers contributes to increasing soil fertility, showed less compacted soils than traditional and intensive ones [66,68]. A decrease in soil depth and soil weight in plots with higher erosion levels was also apparent. This is likely due to the dragging of materials derived from erosion processes and to the fact that the shallower soils are located in intensive groves [71]. An inverse trend with increasing erosion rates was observed for soils with a high content of gravels, which is in accordance with the mitigating effect of such soils according to the criteria set by Lal $[59,60]$. The integrated olive groves showed a higher level of stoniness, thus contributing to the maintenance of a stable soil structure [72]. Although the traditional olive groves showed an intermediate percentage of gravels, this was sharply reduced in intensively managed plots, which are generally affected by soil homogenisation works necessary to facilitate the use of heavy machinery $[70,73]$. Texturally, the highest representation of clays was found in the integrated farms, contributing to the generation of edaphic aggregates, increasing soil stability, and preventing to a large extent the runoff of materials [31,74]. Structurally, less edaphic pores at the higher erosion levels were detected, which can be attributed to soil compaction [75]. Considering that porosity is a mitigating factor for soil erosion, the intensively managed olive groves in the study area were placed over highly compacted soils with few pores, generating highly unstable environments where there are no physical mechanisms to promote the retention of soil materials $[31,59,60]$. Given that the plots in Portugal were characterised by deficit/drip irrigation $[19,41]$, no clear differences related to soil moisture could be observed between the analysed olive managements due to the equitable water supply in all sampled crops.

Chemically, it was observed how soil erosion drives a slight acidification of soils, with the intensive olive groves showing lower $\mathrm{pH}$ values than the integrated and traditional ones. The underlying cause of the observed drop in $\mathrm{pH}$ is likely to be the non-controlled use of synthetic fertilisers, mainly nitrogen, phosphorus, and potassium (i.e., NPK fertilisers) in intensive farms [20,37]. Regarding the organic matter content, a clear correlation was detected between its concentration, the type of olive grove, and level of soil erosion. In this sense, the most eroded soils had a lower organic matter content, a situation that is particularly aggravated in intensive olive groves, where the decrease in soil fertility can ultimately impact agricultural yields in the medium to long term [76,77]. Another factor closely linked to olive grove production is the soil content in potassium cation $[27,28,63]$. While higher soil erosion rates showed a negative relationship with potassium content, because of the loss of edaphic nutrients [71], the highest concentrations of this ion were encountered in intensive groves due to the indiscriminate addition of chemical fertilisers to these crops [21,37].

\subsection{Agronomic Synthesis for the PDO Norte Alentejano}

Despite the great usefulness of the employment of indices based on soil loss tolerance and soil productivity, the applicability of these tools is still incipient [47]. In this sense, there are studies aimed at developing these indices from a methodological point of view, with the research of Li et al. [26] and Duan et al. [28] standing out, while other studies focus their applicability on how erosive processes affect the degradation of calcareous soil environments $[58,63]$. However, their use in agricultural environments and specifically in olive groves is novel, showing in general terms how erosive phenomena lead, in the long term, to the loss of fertility and soil horizons, minimising the sustainability of the crops [31,78-80]. The present research consolidates, together with other similar studies, the necessary bases for the development of specific indices aimed at quantifying the estimation of the economic and environmental sustainability of these agricultural systems [40,63-65]. Taking into account the intrinsic limitations of the indices developed in this research, in which only the existence of linear relationships between edaphic variables and erosion processes was explored, the SLTIog is a more specific and realistic index than the SLTI as it 
takes into account the influence of specific soil parameters as mitigating agents for the loss of soil materials in order to estimate the sustainability of olive groves [31].

In general terms, irrigation is considered an agricultural intensification measure that contributes to soil degradation, negatively affecting the long-term sustainability of agriculture $[12,40]$. However, in the study area, where a deficit/drip irrigation regime predominates in olive groves, the impacts derived from the addition of water to farms as a measure of intensification were minimised, improving water use efficiency and vegetative growth control [79-81]. Specifically, the addition of drip water in areas with water stress can nonetheless enhance the magnitude of soil erosion, driving the need for more efficient and integrated soil-water management practices [31,82]. In this sense, certain soil conservation measures, especially those oriented towards increasing the roughness of soil surface or the implementation of herbaceous plant covers, contribute to avoid soil runoff and nutrient loss [83-85]. Through these practices, a higher soil organic matter content is facilitated, whilst also improving the formation of soil aggregates and reducing compaction $[59,60]$. The results of this study made it possible to verify for the PDO Norte Alentejano that it is possible to move towards more sustainable management practices in olive cultivation in traditional, integrated, and intensive management by using the SLTI and SLTIog as monitoring tools, except for intensively managed and severely eroded plots. The higher sustainability levels were detected in integrated agriculture, a fact that is influenced by the conservation practices characteristic in this management model, highlighting the regulated use of synthetic fertilisers and machinery by technical control agencies and the implementation of partial herbaceous plant covers, measures contributing to increased soil fertility and stability and reducing soil degradation $[20,24,66]$. By contrast, the lower sustainability/durability rates appeared in the intensive olive groves. This is in line with the fact that agricultural intensification responds to a mere demand for increased levels of crop productivity, too often at the expense of key environmental dimensions $[37,70]$.

Finally, it is important to remark how olive groves in the PDO Norte Alentejano showed low-medium values of soil productivity, with the integrated olive grove plots without soil erosion being those with the highest productive potential. Such low productivity rates are due to the low soil potassium contents of the sampled plots and to the equally low percentages of organic matter and clays in the most eroded treatments, which are variables that can be considered key factors in agricultural yields $[27,28,59,63,86]$.

\subsection{Soil and Agronomic Comparison between the PDO Norte Alentejano and PDO Estepa}

After calibrating the USLE model [45-51], it was observed that both the traditional and integrated olive managements in Portugal showed lower soil erosion rates than the integrated ones in Spain. This is probably due to the longer history of olive growing in Southern Spain $[6,14]$. Olive groves in Spain have evolved over millenia and expanded early, resulting in highly eroded soils. However, the organic olive groves in the Estepa region showed the lowest erosion rates out of them all due to the employment of organic fertilisers and the implementation of total plant covers $[68,83,84]$. On the other hand, intensively managed groves in the PDO Norte Alentejano were those with the highest soil erosion rates. In these intensive farms, higher soil erosion rates are correlated with the environmental impacts from the use of agricultural machinery and the addition of fertilisers. These impacts with the absence of herbaceous vegetation covers that increase the retention of soil materials in intensive olive groves make these systems more susceptible to severe erosion processes $[20,37,70,84,87]$.

In comparison with the results reported by Sousa et al. [31], Portuguese olive groves were characterised by higher dry bulk densities, the organic groves in the PDO Estepa being where the least compacted soils were found. This finding results from the lower magnitude of erosion processes and the presence of living plant covers in these crops [88]. The integrated management olive groves in Portugal contained higher values of soil depth and weight, with the traditional and intensive olive groves showing the lowest values. Similarly, soil texture was predominantly loam or sandy-loam in both study areas, with 
a high limestone content, making them highly susceptible to soil erosion [52-55]. Soil porosity was also similar in both regions, with the integrated olive groves of Portugal showing slightly higher values than the Spanish ones. In contrast, the olive groves in the PDO Norte Alentejano showed soil moisture contents equivalent to the irrigated groves surveyed in the PDO Estepa. This is explained by the use of deficit/drip irrigation in both areas [17-20]. Portuguese olive groves had slightly lower $\mathrm{pH}$ values than those of the PDO Estepa, constituting neutral or slightly basic soils in accordance with the Fuentes Yagüe classification [89]. The percentage of soil organic matter in the integrated olive groves in Portugal was higher than that of the organic olive groves in Spain, showing a higher soil fertility rates and thus positively influencing their productive yields [63]. However, the intensive managed plots showed lower fertility rates due to the loss of organic matter, which results in higher levels of soil erosion $[37,90]$. The highest potassium concentration was found in organic crops in Spain, with the Portuguese olive orchards having higher concentrations than those under integrated management practices in the PDO Estepa, but still lower than $170 \mathrm{mg} \mathrm{kg}^{-1}$, thus limiting soil productivity $[27,28]$.

In agronomic terms, the main limitation of the SLTIog model calibrated for the PDO Norte Alentejano consisted of the fact that the same soil parameters were used as in the model developed by Sousa et al. for the PDO Estepa [31]. Although this model presented an $\mathrm{R}^{2}$ of $95.5 \%$ in Spain, in Portugal only an $\mathrm{R}^{2}$ of $51.5 \%$ was obtained. This decrease in the $R^{2}$ is due to the fact that throughout this research the same SLTIog has been implemented for very different types of olive groves in Portugal, resulting in the extreme variability of the data that jointly make up this index. In contrast, data from PDO Estepa were more uniform, which is consistent with the fact that $95 \%$ of the land surveyed being managed under an integrated model $[6,24,31]$. Comparatively, according to the SLTI and SLTIog, the integrated olive groves in Portugal showed the highest soil loss tolerance values, with maximum values of $145.94 \mathrm{tha}^{-1}$ year ${ }^{-1}$ under null erosion conditions. This indicates a degree of sustainability even higher than that in the organic olive groves of the PDO Estepa, which are characterised by values of $140.89 \mathrm{t} \mathrm{ha}^{-1} \mathrm{year}^{-1}$. If soil loss tolerance is defined as the maximum annual soil degradation value permissible to guarantee the sustainability of an agricultural system over time $[58,63,78-80]$, the higher soil loss tolerance detected in the Portuguese integrated olive groves may be due to their shorter history, a fact that would explain that the soil degradation processes hampering the sustainability of these systems may have not yet appeared $[3,4,13]$. In addition, both the traditional and intensive olive groves in Portugal presented lower values of soil loss tolerance than the integrated and organic olive groves of the PDO Estepa, the intensive olive groves being those with the lowest results across the analysed timescale projections. Such lower rates of the intensive olive groves in the PDO Norte Alentejano are in line with the expected environmental impacts generally assumed for intensive management models and also the absence of semi-natural herbaceous plant covers that are capable of mitigating the magnitude of soil erosion processes encountered $[20,37,70,87]$. Although without erosion, it was the Portuguese integrated olive growing that presented the highest soil productivity; with erosive processes, the most productive scenario was the Spanish organic olive groves, given that the environmental practices of this agricultural management (i.e., organic fertilisers and plant covers) contribute to maximising soil conservation and fertility $[66,88,90]$. By contrast, the lowest productivity scenario was the intensive olive grove under severe erosion. This is explained by soil degradation and loss of nutrients (i.e., potassium), organic matter, and the generation of more compacted soils as a consequence of erosive processes $[27,56,76,77]$.

Taking into account the results obtained, which show how the presence of plant covers in integrated and organic farming has a positive influence on the durability of olive groves, it is highly recommended that the implementation of farming practices characteristic of multifunctional agriculture be promoted from a legislative and political point of view, thus contributing to increasing agricultural sustainability $[6,15,83,84,88]$. In this regard, it should be noted that the current Common Agricultural Policy (i.e., CAP post-2020) includes within its structure a specific pillar for non-production-based aid, 
aimed at promoting rural development and soil conservation measures such as those commonly used in organic farming (i.e., minimal use of machinery, non-synthetic fertilisers, and avoiding bare soil), with a commitment to enhancing the value of productive and non-productive ES in agriculture in accordance with the current demands of society, mainly related to stable food supply and food security [24,91,92].

\section{Conclusions}

Considering the recent boom of olive grove expansion and intensification in Southern and Central Portugal, we hypothesise that not enough time may have yet elapsed to adequately assess the different soil impacts of different farm and olive grove management models in the study area. In this sense, it is important to highlight how erosive processes are influenced by the topological and edaphological characteristics of the territory, in addition to the agricultural practices carried out. Thus, erosion processes in olive groves are highly influenced by the slope of the territory, which favours runoff phenomena and the appearance of gullies. In general terms, integrated management showed the lowest erosion rates, most probably explained by the implementation of agricultural conservation practices that are generally absent from traditional and intensive management models. The SLTI and SPI indices prove to be relevant and innovative tools that allow us to know the conservation status of olive grove plots and, consequently, to adopt measures aimed at minimising the environmental impacts of agricultural practices. Specifically, the SLTIog, which is specifically tailored for olive groves, provides a more realistic indicator than the SLTI, which is generic for any other agricultural system. By incorporating the influence of different soil erosion mitigating factors, it is possible to estimate the admissible annual soil losses to ensure the maintenance of agricultural production across scales ranging from the short to the long-terms. The results showed a higher SLTI and SLTIog for the integrated olive crops in the PDO Norte Alentejano compared to the traditional and intensive ones, the latter being the management model with the lowest long-term sustainability standards.

Compared to the PDO Estepa in Spain, where olive groves are already the matrix of a monocultural landscape with a deep-rooted history, Portuguese integrated olive groves were detected to be those characterised by higher soil loss tolerance rates, even higher than the integrated and organic olive groves in Spain. However, the results obtained for traditional and intensive olive groves in the PDO Norte Alentejano suggested a lower potential for agronomic sustainability than the Spanish olive groves considering any of the various soil erosion levels. Similarly, the integrated olive groves in Portugal were also those that showed the highest soil productivity (with an intermediate level).

Finally, it is important to remark that although this comparative study provides relevant information on the state and future prospects for soil conservation of Portuguese and Spanish olive groves, it has the limitation of not having considered other possible soil parameters as erosion mitigating agents. Future studies which explore the relationship between the soil environment and agricultural sustainability should lay the foundations for the development of policies that promote the implementation of agri-environmental measures aimed at maximising the productive and environmental sustainability of agriculture. In this sense, it is necessary to carry out research aimed at the generation of ad hoc models adapted to each olive grove management considered in their respective contexts. This would permit assessing the potential consideration of soil variables that become apparent at the regional or local levels, potentially acting as mitigating agents of soil erosion processes, whilst also incorporating statistical models that are important to elucidate possible nonlinear relationships and interactions between each of these variables and final soil erosion rates.

Author Contributions: Conceptualization, A.A.R.S. and A.J.R.; methodology, A.A.R.S.; software, A.A.R.S. and J.M.B.; validation, J.M.-R., T.P.-C., P.A.A. and A.J.R.; formal analysis, A.A.R.S. and J.M.-R.; investigation, A.A.R.S., J.M.-R. and T.P.-C.; resources, A.A.R.S., J.M.B. and A.J.R.; data curation, A.A.R.S.; writing-original draft preparation, A.A.R.S.; writing-review and editing, A.A.R.S., J.M.-R. and A.J.R.; visualization, A.A.R.S., J.M.B. and A.J.R.; supervision, T.P.-C., P.A.A. and 
A.J.R.; project administration, P.A.A. and A.J.R.; funding acquisition, P.A.A. All authors have read and agreed to the published version of the manuscript.

Funding: This research received no external funding.

Institutional Review Board Statement: Not applicable.

Informed Consent Statement: Not applicable.

Data Availability Statement: Not applicable.

Acknowledgments: To the University Complutense of Madrid, for awarding the lead author a short-term fellowship through which this research could be carried out. To MED-Universidade de Évora (Portugal), for providing to the main author with the opportunity to jointly perform field work and analytical tasks in Portugal. The time devoted by J.M.-R. and T.P.-C. to retrieve and treat the data and to write and revise the article has received partial funding from the following sources: (a) FCT—Foundation for Science and Technology (Portugal) under the Project UIDB/05183/2020; (b) SUSTAINOLIVE research project (https:/ / sustainolive.eu/?lang=en [accessed on: 29 March 2021]), funded by the PRIMA EU program. Lastly, we thank María Aurora Rodríguez Sousa for her support and advice.

Conflicts of Interest: The authors declare no conflict of interest.

\section{References}

1. EUROSTAT. Farm Structure Statistics; Eurostat (European Statistics): Brussels, Belgium, 2018. Available online: https:/ / ec.europa. eu/eurostat/statistics-explained/index.php?title=Farm_structure_statistics/es (accessed on 21 January 2021).

2. IOC. Market Newsletter November 2015; IOC (International Olive Council): Madrid, Spain, 2015. Available online: https://www. internationaloliveoil.org (accessed on 12 January 2021).

3. INE. Agriculture, Forestry and Fishing; INE (Instituto Nacional de Estadística/Statistical Spanish Office): Madrid, Spain, 2013. Available online: http:/ / www.ine.es (accessed on 23 January 2021).

4. IOC. Olive Oil Provisional Data 2018/2019 Crop Year; IOC (International Olive Council): Madrid, Spain, 2018. Available online: http:/ / www.internationaloliveoil.org/olive-oil-provisional-data-2018-19-crop-year/ (accessed on 11 January 2021).

5. Hernández, J.V.; Gámez, M.D.M.V.; Poyatos, R.P.; Cerámica, P.L.C. Incidencia del modo de explotación del olivo sobre la renta neta del olivicultor. Estrategias para el cultivo extensivo en el contexto de la posible ausencia de subvenciones. Grasas Aceites 2010, 61, 430-440. (In Spanish) [CrossRef]

6. BOJA. Plan Director del Olivar Andaluz Decreto 103/2015; BOJA (Boletín Oficial de la Junta de Andalucía/Official Regional Government of Andalusia Bulletin): Sevilla, Spain, 2015. Available online: http:/ /www.webcitation.org/77MO1YwQe (accessed on 20 January 2021). (In Spanish)

7. Balzan, M.V.; Sadula, R.; Scalvenzi, L. Assessing ecosystem services supplied by agroecosystems in Mediterranean Europe: A iterature review. Land 2020, 9, 245. [CrossRef]

8. IOC. Olive Oil Estimates 2019/20 Crop Year; IOC (International Olive Council): Madrid, Spain, 2019. Available online: https: //www.internationaloliveoil.org/olive-oil-estimates-2019-20-crop-year/ (accessed on 10 January 2021).

9. Torres-Miralles, M.; Grammatikopoulou, I.; Rescia, A.J. Employing contingent and inferred valuation methods to evaluate the conservation of olive groves and associated ecosystem services in Andalusia (Spain). Ecosyst. Serv. 2017, 26, 258-269. [CrossRef]

10. Bidegain, I.; López-Santiago, C.A.; González, J.A.; Martínez-Sastre, R.; Ravera, F.; Cerda, C. Social Valuation of Mediterranean Cultural Landscapes: Exploring Landscape Preferences and Ecosystem Services Perceptions through a Visual Approach. Land 2020, 9, 390. [CrossRef]

11. Salazar-Ordóñez, M.; Rodríguez-Entrena, M.; Villanueva, A.J. Exploring the commodification of biodiversity using olive oil producers' willingness to accept. Land Use Policy 2020, 104348. [CrossRef]

12. Gómez-Limón, J.A.; Picazo-Tadeo, A.J.; Reig-Martínez, E. Eco-efficiency assessment of olive farms in Andalusia. Land Use Policy 2012, 29, 395-406. [CrossRef]

13. Fraga, H.; Pinto, J.G.; Santos, J.A. Olive tree irrigation as a climate change adaptation measure in Alentejo, Portugal. Agric. Water Manag. 2020, 237, 106193. [CrossRef]

14. BOE. Ley 5/2011, de 6 de Octubre, del Olivar de Andalucía; BOE (Boletín Oficial del Estado/State Official Bulletin): Andalusia, Spain, 2011. Available online: https:/ / www.boe.es/buscar/act.php?id=BOE-A-2011-17494 (accessed on 16 January 2021). (In Spanish)

15. EUR-lex. Reglamento (CE) $n^{\circ} 708 / 2005$ de la Comisión, de 10 de Mayo de 2005, por el que se Modifican Algunos Elementos del Pliego de Condiciones de una Denominación de Origen que Figura en el Anexo del Reglamento (CE) $n^{\circ}$ 1107/96 (Azeites do Norte Alentejano) (DOP); EUR-lex (European Union): Brussels, Belgium, 2005. Available online: https:/ / eur-lex.europa.eu/legal-content/ES/ALL/?uri= CELEX:32005R0708 (accessed on 18 January 2021). (In Spanish)

16. EC. El Aceite de Olive en la UE.; EC (European Comission): Brussels, Belgium, 2020. Available online: https:/ / ec.europa.eu (accessed on 18 January 2021). (In Spanish) 
17. Iniesta, F.; Testi, L.; Orgaz, F.; Villalobos, F.J. The effects of regulated and continuous deficit irrigation on the water use, growth and yield of olive trees. Eur. J. Agron. 2009, 30, 258-265. [CrossRef]

18. Romero-Gámez, M.; Castro-Rodríguez, J.; Suárez-Rey, E.M. Optimization of olive growing practices in Spain from a life cycle assessment perspective. J. Clean. Prod. 2017, 149, 25-37. [CrossRef]

19. Pérez, J.R.; Loureiro, S.; Menezes, S.; Palma, P.; Fernandes, R.M.; Barbosa, I.R.; Soares, A.M. Assessment of water quality in the Alqueva Reservoir (Portugal) using bioassays. Environ. Sci. Pollut. R. 2010, 17, 688-702. [CrossRef]

20. AEMO. Aproximación a los Costes del Cultivo del Olivo. Cuaderno de Conclusiones del Seminario AEMO.; AEMO (Asociación Española de Municipios del Olivo/Spanish Association of Municipalities of Olive Groves): Córdoba, Spain, 2012. Available online: http:/ / www.webcitation.org/77MCvuNPx (accessed on 23 January 2021). (In Spanish)

21. Loumou, A.; Giourga, C. Olive groves: “The life and identity of the Mediterranean”. Agric. Hum. Val. 2003, 20, 87-95. [CrossRef]

22. Caraveli, H. A comparative analysis on intensification and extensification in Mediterranean agriculture: Dilemmas for LFAs policy. J. Rural Stud. 2000, 16, 231-242. [CrossRef]

23. Sal, A.G.; García, A.G. A comprehensive assessment of multifunctional agricultural land-use systems in Spain using a multidimensional evaluative model. Agric. Ecosyst. Environ. 2007, 120, 82-91. [CrossRef]

24. Rodríguez Sousa, A.A.; Parra-López, C.; Sayadi-Gmada, S.; Barandica, J.M.; Rescia, A.J. A multifunctional assessment of integrated and ecological farming in olive agroecosystems in southwestern Spain using the Analytic Hierarchy Process. Ecol. Econom. 2020, 173, 106658. [CrossRef]

25. Lombardi-Neto, F.; Bertoni, J. Tolerância de perdas de terra para solos do Estado de São Paulo. Bol. Tec. Inst. Agron. 1975, $28,12$.

26. Li, L.; Du, S.; Wu, L.; Liu, G. An overview of soil loss tolerance. Catena 2009, 78, 93-99. [CrossRef]

27. Duan, X.W.; Yun, X.; Feng, Y.J.; Yin, S.Q. Study on the method of soil productivity assessment in black soil region of Northeast China. Agric. Sci. China 2009, 8, 472-481. [CrossRef]

28. Duan, X.; Shi, X.; Li, Y.; Rong, L.; Fen, D. A new method to calculate soil loss tolerance for sustainable soil productivity in farmland. Agron. Sustain. Dev. 2017, 37, 2. [CrossRef]

29. Albuquerque, T.G.; Costa, H.S.; Oliveira, M.B.P. An Overview of Portuguese Olive Oils and Table Olives with Protected Designation of Origin. Eur. J. Lipid Sci. Technol. 2019, 121, 1800129. [CrossRef]

30. Rodríguez Sousa, A.A.; Barandica, J.M.; Rescia, A.J. Application of a dynamic model using agronomic and economic data to evaluate the sustainability of the olive grove landscape of Estepa (Andalusia, Spain). Landsc. Ecol. 2019, 34, 1547-1563. [CrossRef]

31. Rodríguez Sousa, A.A.; Barandica, J.M.; Rescia, A.J. Estimation of Soil Loss Tolerance in Olive Groves as an Indicator of Sustainability: The Case of the Estepa Region (Andalusia, Spain). Agronomy 2019, 9, 785. [CrossRef]

32. Godinho, S.; Santos, A.P.; Sá-Sousa, P. Montado management effects on the abundance and conservation of reptiles in Alentejo, Southern Portugal. Agroforest. Syst. 2011, 82, 197-207. [CrossRef]

33. Surová, D.; Pinto-Correia, T.; Marušák, R. Visual complexity and the montado do matter: Landscape pattern preferences of user groups in Alentejo, Portugal. Ann. For. Sci. 2014, 71, 15-24. [CrossRef]

34. Allen, H.; Simonson, W.; Parham, E.; Santos, E.D.B.E.; Hotham, P. Satellite remote sensing of land cover change in a mixed agro-silvo-pastoral landscape in the Alentejo, Portugal. Int. J. Remote Sens. 2018, 39, 4663-4683. [CrossRef]

35. Morais, T.G.; Silva, C.; Jebari, A.; Álvaro-Fuentes, J.; Domingos, T.; Teixeira, R.F. A proposal for using process-based soil models for land use Life cycle impact assessment: Application to Alentejo, Portugal. J. Clean. Prod. 2018, 192, 864-876. [CrossRef]

36. Rodrigues, A.R.; e Silva, F.C.; Correia, A.C.; Bicho, M.C.; Madeira, M.; Coutinho, J. Do improved pastures enhance soil quality of cork oak woodlands in the Alentejo region (Portugal)? Agroforest. Syst. 2020, 94, 125-136. [CrossRef]

37. Cameira, M.R.; Pereira, A.; Ahuja, L.; Ma, L. Sustainability and environmental assessment of fertigation in an intensive olive grove under Mediterranean conditions. Agric. Water Manag. 2014, 146, 346-360. [CrossRef]

38. Andrade Capela da SilvaCarrilho, D. Estudio y Análisis Hidráulico y Energético del Riego de la Finca "Barbeiras". Master's Thesis, Universidad de Jaén, Andalusia, Spain, 2017. Available online: http://tauja.ujaen.es/handle/10953.1/6146 (accessed on 25 January 2021).

39. Veloso, M.M.; Simões-Costa, M.C.; Carneiro, L.C.; Guimarães, J.B.; Mateus, C.; Fevereiro, P.; Pinto-Ricardo, C. Olive Tree (Olea europaea L.) diversity in traditional small farms of Ficalho, Portugal. Diversity 2018, 10, 5. [CrossRef]

40. Rodríguez Sousa, A.A.; Barandica, J.M.; Rescia, A. Ecological and economic sustainability in olive groves with different irrigation management and levels of erosion: A case study. Sustainability 2019, 11, 4681. [CrossRef]

41. Palma, P.; Ledo, L.; Soares, S.; Barbosa, I.R.; Alvarenga, P. Spatial and temporal variability of the water and sediments quality in the Alqueva reservoir (Guadiana Basin; southern Portugal). Sci. Total Environ. 2014, 470, 780-790. [CrossRef]

42. Rocha, J.; Carvalho-Santos, C.; Diogo, P.; Beça, P.; Keizer, J.J.; Nunes, J.P. Impacts of climate change on reservoir water availability, quality and irrigation needs in a water scarce Mediterranean region (southern Portugal). Sci. Total Environ. 2020, 736, 139477. [CrossRef]

43. CORINE Land Cover. Copernicus Land Monitoring Service; CORINE Land Cover: Copenhagen, Denmark, 2021. Available online: https: / land.copernicus.eu/pan-european/corine-land-cover (accessed on 23 January 2021).

44. Epic WebGIS Portugal. Ecological Planning, Investigation and Cartography; Epic WebGIS Portugal: Lisbon, Portugal, 2021. Available online: http:/ / epic-webgis-portugal.isa.ulisboa.pt/ (accessed on 21 January 2021).

45. Wischmeier, W.H.; Smith, D.D. A Universal Soil-Loss Equation to Guide Conservation Farm Planning, 1st ed.; International Society of Soil Science: Madison, WI, USA, 1961; pp. 418-425. 
46. Fistikoglu, O.; Harmancioglu, N.B. Integration of GIS with USLE in assessment of soil erosion. Water Resour. Manag. 2002, 16, 447-467. [CrossRef]

47. Moreira-Madueño, J.M. Capacidad de Uso y Erosión de Suelos. Una Aproximación a la Evaluación de Tierras en Andalucía; Junta de Andalucía, Agencia del Medio Ambiente: Sevilla, Spain, 1991. Available online: http://www.juntadeandalucia. es/medioambiente/web/Red_informacion_ambiental/productos/Publicaciones/articulos/articulos_pdf/Paralelo.PDF (accessed on 11 January 2021). (In Spanish)

48. Santisteban, L.D.; Casalí, J.; López, J.J.; Giráldez, J.V.; Poesen, J.; Nachtergaele, J. Exploring the role of topography in small channel erosion. Earth Surface Processes and Landforms. J. Br. Geomorphol. Res. Group 2005, 30, 591-599. [CrossRef]

49. Gisbert Blanquer, J.M.; Ibañez Asensio, S.; Moreno Ramón, H. El Factor K de la Ecuación Universal de Pérdidas de Suelo (USLE); Universitat Politècnica de València: Valencia, Spain, 2012. Available online: http://hdl.handle.net/10251/16850 (accessed on 12 January 2021). (In Spanish)

50. Auerswald, K.; Fiener, P.; Martin, W.; Elhaus, D. Use and misuse of the K factor equation in soil erosion modeling: An alternative equation for determining USLE nomograph soil erodibility values. Catena 2014, 118, 220-225. [CrossRef]

51. Gómez, J.A.; Battany, M.; Renschler, C.S.; Fereres, E. Evaluating the impact of soil management on soil loss in olive orchards. Soil Use Manag. 2003, 19, 127-134. [CrossRef]

52. Narayanan, N.; Ramamurthy, K. Structure and properties of aerated concrete: A review. Cem. Concr. Compos. 2000, 22, 321-329. [CrossRef]

53. Helson, O.; Beaucour, A.L.; Eslami, J.; Noumowe, A.; Gotteland, P. Physical and mechanical properties of soilcrete mixtures: Soil clay content and formulation parameters. Constr. Build. Mater. 2017, 131, 775-783. [CrossRef]

54. Bouyoucos, G.J. A Recalibration of the hydrometer method for making mechanical analysis of soils. Agron J. 1951, 43, 434-438. [CrossRef]

55. Vaezi, A.R.; Hasanzadeh, H.; Cerda, A. Developing an erodibility triangle for soil textures in semi-arid regions, NW Iran. Catena 2016, 142, 221-232. [CrossRef]

56. Laudicina, V.A.; Novara, A.; Barbera, V.; Egli, M.; Badalucco, L. Long-term tillage and cropping system effects on chemical and biochemical characteristics of soil organic matter in a Mediterranean semiarid environment. Land Degrad. Dev. 2015, 26, 45-53. [CrossRef]

57. Afolayan, O.S.; Oderinde, F.O. Evaluation of deterioration index in soil nutrients due to cultivation of different cocoa species in southwest Nigeria. J. Appl. Sci. Environ. Manag. 2018, 22, 547-552. [CrossRef]

58. Liu, G.; Li, L.; Wu, L.; Wang, G.; Zhou, Z.; Du, S. Determination of soil loss tolerance of an entisol in Southwest China. Soil Sci. Soc. Am. J. 2009, 73, 412-417. [CrossRef]

59. Lal, R. Soil erosion and carbon dynamics. Soil Till. Res. 2005, 81, 137-142. [CrossRef]

60. Lal, R. Accelerated soil erosion as a source of atmospheric CO2. Soil Till. Res. 2019, 188, 35-40. [CrossRef]

61. González, C.G.; Lise, A.V.; Felpeto, A.B. Tratamiento de Datos con R, Statistica y SPSS, 1st ed.; Ediciones Díaz de Santos: Madrid, Spain, 2013; pp. 217-415. (In Spanish)

62. RStudio. Open Source and Enterprise-Ready Professional Software for R; RStudio Version 0.98.1102; RStudio Inc.: Boston, MA, USA, 2009. Available online: https:/ / www.rstudio.com/products/RStudio/ (accessed on 1 January 2021).

63. Duan, X.; Xie, Y.; Liu, B.; Liu, G.; Feng, Y.; Gao, X. Soil loss tolerance in the black soil region of Northeast China. J. Geogr. Sci. 2012, 22, 737-751. [CrossRef]

64. Montgomery, D.R. Soil erosion and agricultural sustainability. Proc. Natl. Acad. Sci. USA 2007, 104, 13268-13272. [CrossRef] [PubMed]

65. Renting, H.; Rossing, W.A.H.; Groot, J.C.J.; Van der Ploeg, J.D.; Laurent, C.; Perraud, D.; Stobbelaar, D.J.; Van Ittersum, M.K. Exploring multifunctional agriculture. A review of conceptual approaches and prospects for an integrative transitional framework. J. Environ. Manag. 2009, 90, S112-S123. [CrossRef]

66. Maffia, A.; Pergola, M.; Palese, A.M.; Celano, G. Environmental impact assessment of organic vs. integrated olive-oil systems in Mediterranean context. Agronomy 2020, 10, 416. [CrossRef]

67. Tilman, D.; Balzer, C.; Hill, J.; Befort, B.L. Global food demand and the sustainable intensification of agriculture. Proc. Natl. Acad. Sci. USA 2011, 108, 20260-20264. [CrossRef]

68. Gómez, J.A.; Giráldez, J.V.; Pastor, M.; Fereres, E. Effects of tillage method on soil physical properties, infiltration and yield in an olive orchard. Soil Till. Res. 1999, 52, 167-175. [CrossRef]

69. Tolón-Becerra, A.; Botta, G.F.; Lastra-Bravo, X.; Tourn, M.; Rivero, D. Subsoil compaction from tractor traffic in an olive (Olea europea L.) grove in A lmería, S pain. Soil Use Manag. 2012, 28, 606-613. [CrossRef]

70. Metzidakis, I.; Martinez-Vilela, A.; Nieto, G.C.; Basso, B. Intensive olive orchards on sloping land: Good water and pest management are essential. J. Environ. Manag. 2008, 89, 120-128. [CrossRef]

71. Gómez, J.A.; Sobrinho, T.A.; Giráldez, J.V.; Fereres, E. Soil management effects on runoff, erosion and soil properties in an olive grove of Southern Spain. Soil Till. Res. 2009, 102, 5-13. [CrossRef]

72. Sastre, B.; Marques, M.J.; García-Díaz, A.; Bienes, R. Three years of management with cover crops protecting sloping olive groves soils, carbon and water effects on gypsiferous soil. Catena 2018, 171, 115-124. [CrossRef]

73. Nasini, L.; Proietti, P. Olive harvesting. In The Extra-Virgin Olive Oil Handbook; John Wiley \& Sons Ltd.: Hoboken, NJ, USA, 2014; pp. 87-105. [CrossRef] 
74. Almajmaie, A.; Hardie, M.; Acuna, T.; Birch, C. Evaluation of methods for determining soil aggregate stability. Soil Till. Res. 2017, 167, 39-45. [CrossRef]

75. Fu, Y.; Tian, Z.; Amoozegar, A.; Heitman, J. Measuring dynamic changes of soil porosity during compaction. Soil Till. Res. 2019, 193, 114-121. [CrossRef]

76. Bauer, A.; Black, A.L. Quantification of the effect of soil organic matter content on soil productivity. Soil Sci. Soc. Am. J. 1994, 58, 185-193. [CrossRef]

77. Oldfield, E.E.; Bradford, M.A.; Wood, S.A. Global meta-analysis of the relationship between soil organic matter and crop yields. Soil 2019, 5, 15-32. [CrossRef]

78. Chandel, S.; Hadda, M.S. Assessment of soil loss tolerance. Int. J. Farm Sci. 2017, 7, 101-109. Available online: https:/ /www indianjournals.com (accessed on 5 February 2021).

79. Li, Y.; Bai, X.Y.; Wang, S.J.; Qin, L.Y.; Tian, Y.C.; Luo, G.J. Evaluating of the spatial heterogeneity of soil loss tolerance and its effects on erosion risk in the carbonate areas of southern China. Solid Earth 2017, 8, 661-669. [CrossRef]

80. Ostovari, Y.; Moosavi, A.A.; Pourghasemi, H.R. Soil loss tolerance in calcareous soils of a semiarid region: Evaluation, prediction, and influential parameters. Land Degrad. Dev. 2020, 31, 2156-2167. [CrossRef]

81. Liu, Q.; Lan, Y.; Tan, F.; Tu, Y.; Sun, Y.; Yougu, G.; Yang, Z.; Ding, C.; Li, T. Drip irrigation elevated olive productivity in Southwest China. HortTechnology 2019, 29, 122-127. [CrossRef]

82. García-Ruiz, J.M. The effects of land uses on soil erosion in Spain: A review. Catena 2010, 81, 1-11. [CrossRef]

83. Zuazo, V.D.; Martínez, J.F.; Pleguezuelo, C.R.; Raya, A.M.; Rodríguez, B.C. Soil-erosion and runoff prevention by plant covers in a mountainous area (SE Spain): Implications for sustainable agriculture. Environmentalist 2006, 26, 309-319. [CrossRef]

84. Zuazo, V.H.D.; Pleguezuelo, C.R.R. Soil-erosion and runoff prevention by plant covers: A review. J. Sustain. Agric. 2009, 785-811. [CrossRef]

85. Fernández, T.; Pérez-García, J.L.; Gómez-López, J.M.; Cardenal, J.; Calero, J.; Sánchez-Gómez, M.; Delgado, J.; Tovar-Pescador, J. Multitemporal analysis of gully erosion in olive groves by means of digital elevation models obtained with aerial photogrammetric and LiDAR data. ISPRS Int. J. Geo. Inf. 2020, 9, 260. [CrossRef]

86. Bashagaluke, J.B.; Logah, V.; Opoku, A.; Sarkodie-Addo, J.; Quansah, C. Soil nutrient loss through erosion: Impact of different cropping systems and soil amendments in Ghana. PLoS ONE 2018, 13, e0208250. [CrossRef]

87. Rodríguez Sousa, A.A.; Barandica, J.M.; Aguilera, P.A.; Rescia, A.J. Examining Potential Environmental Consequences of Climate Change and Other Driving Forces on the Sustainability of Spanish Olive Groves under a Socio-Ecological Approach. Agriculture 2020, 10, 509. [CrossRef]

88. Pleguezuelo, C.R.R.; Zuazo, V.H.D.; Martínez, J.R.F.; Peinado, F.J.M.; Martín, F.M.; Tejero, I.F.G. Organic olive farming in Andalusia, Spain. A review. Agron. Sustain. Dev. 2018, 38, 1-16. [CrossRef]

89. Fuentes Yagüe, J.L. Manual práctico de Manejo del Suelo y de los Fertilizantes, 1st ed.; Ministerio de Agricultura Pesca y Alimentación: Madrid, Spain, 1997; p. 159. (In Spanish)

90. Parras-Alcántara, L.; Díaz-Jaimes, L.; Lozano-García, B. Organic farming affects C and N in soils under olive groves in Mediterranean areas. Land Degrad. Dev. 2015, 26, 800-806. [CrossRef]

91. EC. The Attitudes of European Citizens towards Environment; Special Eurobarometer 217/Wave 62.1 TNS Opinion \& Social; EC (European Commission): Brussels, Belgium, 2005. Available online: https://ec.europa.eu/commfrontoffice/publicopinion/ archives/ebs/ebs_217_en.pdf (accessed on 20 March 2021).

92. EC. Europeans, Agriculture and the CAP; TNS Opinion \& Social. Special Eurobarometer 440; EC (European Comission): Brussels, Belgium, 2016. Available online: http:/ / data.europa.eu/euodp/en/data/dataset/S2087_84_2_440_ENG (accessed on 20 March 2021). 